\title{
Primary Production in Lake Kasumigaura, 1981-1985
}

\author{
Noriko TAKamURa, Toshio IwakUma, and Masayuki Yasuno
}

\begin{abstract}
The seasonal succession of phytoplankton was investigated from 1978 to 1985 and the primary production was examined from 1981 to 1985 in Lake Kasumigaura. A large bloom of Microcystis spp. was observed every summer. Synedra rumpens and S. acus dominated in spring, and Melosira granulata, Coscinodiscus lacustris, Cyclotella spp., and/or Chrysochromulina sp. dominated in autumn and winter. Exceptionally large blooms of Closterium aciculare and Oscillatoria agardhii were observed in spring of 1979 and in autumn of 1982 , respectively. The gross primary production correlated significantly with the water temperature, the solar radiation, and the chlorophyll a concentration, but not with the nutrient concentrations by multiple regression analysis. Therefore the nutrients were not limiting factors for the primary production in this lake. The annual gross primary production at a center of this lake ranged from 483 to $734 \mathrm{gC} \cdot \mathrm{m}^{-2} \cdot \mathrm{yr}^{-1}$, which was intermediate among the values reported in other lakes with Microcystis bloom.
\end{abstract}

Key words : Microcystis, succession, primary production, water bloom.

\section{Introduction}

Cyanobacteria such as Microcystis, Anabaena, and Aphanizomenon had already appeared in 1910 in Lake Kasumigaura (Ibaraki Prefecture, 1912). However, it would be neither abundant nor dominant then. The Ibaraki Prefecture Government (TANGE et al., 1957 ; KASEBAYASHI et al., 1957, 1959a, 1959b ; SUNOU et al., 1960 ; YAGUCHI et al., $1961 \mathrm{a}, 1961 \mathrm{~b})$ reported the abundance of phytoplankton collected with a plankton net during $1950-$ 1960. According to them, the most dominant species in the summer changed from Melosira to Microcystis after 1957. SUGIURA et al. (1978, 1982) reported that Microcystis bloomed every year from 1969 to 1978 at the innermost part of Tsuchiurairi Bay, and it became dominant in 1971, 1972, and 1973 in the main basin.

The primary production in this lake was measured first by ICHIMURA (1958, 1960a, b, 1961). The values of chlorophyll $a$ concentration and gross primary production in $1956-1957$ were $10-40 \mathrm{mg} \cdot \mathrm{m}^{-3}$ and $0.1-2.2 \mathrm{gO}_{2} \cdot \mathrm{m}^{-2} \cdot \mathrm{d}^{-1}$, respectively. Thereafter, the primary production during 1971-1979 was measured by MAEDA et al. (1974), TEZUKA et al. (1973, 1975), IWAKUMA and AIZAKI (1979) and IWAKUMA and YASUNO (1981). The annual means of gross primary production in the main basin were $4.6 \mathrm{gO}_{2} \cdot \mathrm{m}^{-2} \cdot \mathrm{d}^{-1}$ in 1972-1973 (TEZUKA et al., 1973), $7.0 \mathrm{gO}_{2} \cdot \mathrm{m}^{-2} \cdot \mathrm{d}^{-1}$ in 1973-1974 (TEZUKA et al., 1975), and $9.0 \mathrm{gO}_{2} \cdot \mathrm{m}^{-2}$. $\mathrm{d}^{-1}$ in 1979 (IwAKUMA and Y ASUNO, 1981), respectively.

This study reports the seasonal changes in the biomass of phytoplankton species during 1978-1985 and the primary production in Lake Kasumigaura during 1981-1985. Also, factors controlling the primary production of this lake are analyzed.

\section{Geographic situation of Lake Kasumigaura}

Lake Kasumigaura which is located in Kanto Plain $\left(35^{\circ} 52^{\prime} \mathrm{N}-36^{\circ} 09^{\prime} \mathrm{N}, 140^{\circ} 13^{\prime} \mathrm{E}-140^{\circ} 38^{\prime} \mathrm{E}\right)$ is the second largest lake in Japan (surface area, $167.7 \mathrm{~km}^{2}$ ). The maximum depth and the mean depth of this lake are $7.3 \mathrm{~m}$ and $4.0 \mathrm{~m}$, respectively (Fig. 1). The area of its drainage basin is $1,949 \mathrm{~km}^{2}$. The lake has 26 small inflows and one outflow (Hitachitone River). The volume is $848 \times 10^{6} \mathrm{~m}^{3}$ and its retention time was calculated to be 1.3 years.

\section{Methods}

\section{3-1. Sampling and measurements of environmental factors}

Sampling stations are shown in Figure 1. Water samples were taken at $0.5 \mathrm{~m}$ depth with a Van- 
Dorn water sampler from March 1978 to March 1981 and from the surface to $2.0 \mathrm{~m}$ depth with an acrylic tube of $4.3 \mathrm{~cm}$ in diameter from April 1981 to March 1986. Water temperature, dissolved oxygen, $\mathrm{pH}$, transparency and underwater solar irradiation were measured biweekly, in some cases monthly, with a thermistor electrodes (Hydro labo 8000), a Secchi disc and a quantum sensor (LI-COR, LI-192S or Biosphaerical QSP 170), respectively.

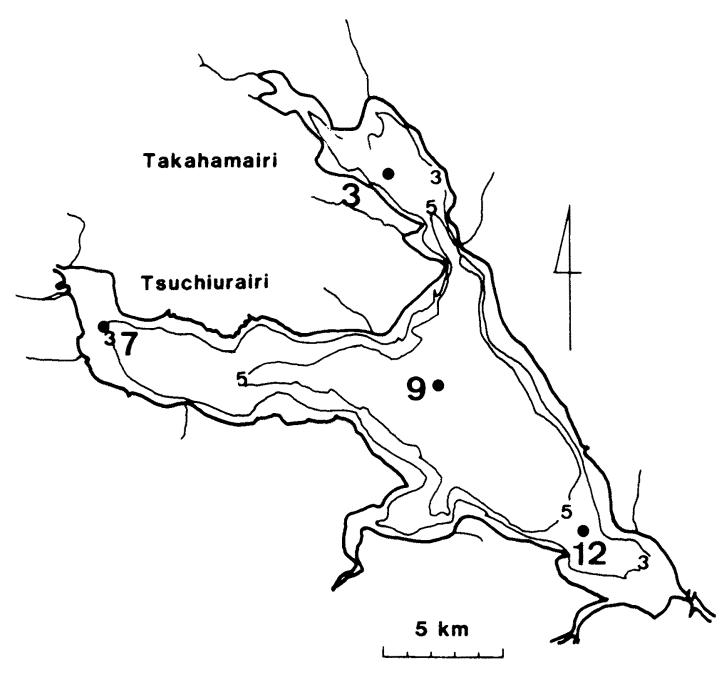

Fig. 1. Map of Lake Kasumigaura showing sampling stations. Depth contours in meters.

\section{3-2. Species composition and algal biomass}

The counting of phytoplankton fixed with Lugol's iodine solution was performed by UTERMÖHL's method (1958). Microcystis cells were counted with a haemacytometer after being dispersed by ultrasonic disintegration $(20 \mathrm{kHz}, 60 \mathrm{sec})$. The species and their volume appeared from 1978 to 1985 in this lake were already shown in our previous report (TAKAMURA et al., 1986). The carbon content of each species was converted using their volume by STRATHMANN (1967). The biomass of each alga was determined by the cell numbers and its carbon content.

\section{3-3. Primary production}

3-3-1. Measurement of biomass (chlorophyll $a$ and $\mathrm{POC}$ ), photosynthesis and respiration

All samples were prefiltered through a $193 \mu \mathrm{m}$ mesh net to remove large zooplankton. Chlorophyll $a$ was extracted in $90 \%$ acetone and determined spectrophotometrically by the UNESCO/SCOR method
(UNESCO/SCOR 1966), after the water samples were quantitatively filtered through a Whatman GF/C filter. The carbon content was measured with a CHN analyzer (Yanagimoto MT-3) after collection on a Whatman GF/C filter precombusted at $450^{\circ} \mathrm{C}$ for $3 \mathrm{hr}$.

To measure carbon uptake, $0.5 \mathrm{ml}$ of $\mathrm{NaH}^{13} \mathrm{CO}_{3}$ solution $\left(0.5 \mathrm{mg} \cdot 1^{-1}\right)$ was added to water sample in each $100 \mathrm{ml}$ BOD bottle, all of which were incubated at five light intensity levels (20,50,100, 300 and $1,000 \mu$ Einst. $\left.\mathrm{m}^{-2} \cdot \mathrm{s}^{-1}\right)$ in a water tank set at in situ water temperature. Since the incubation for more than two hours resulted in the reduction of photosynthesis, the incubation time was restricted for one hour. The light sources used were four $300 \mathrm{~W}$ tungsten lamps. To provide uniform light intensity and mix the samples in bottles, transparent acrylic boards ( $40 \mathrm{~cm}$ in diameter) with BOD bottles were rotated at the speed of $10 \mathrm{rpm}$ facing light. The light intensity was reduced by placing opaque acrylic boards between the transparent acryl boards. After the incubation, the BOD bottles were transferred to a dark box with ice. Phytoplankton in these bottles were collected on a precombusted $\left(450^{\circ} \mathrm{C}, 3 \mathrm{hr}\right)$ Whatman $\mathrm{GF} / \mathrm{C}$ filter under a dim light. The concentrations of organic carbon and the isotope ratios of ${ }^{13} \mathrm{C}$ and ${ }^{12} \mathrm{C}$ in the samples were determined with a quadrupole mass-spectrometer facilitated with a combustion furnace (ANELBA TE-150). The concentrations of inorganic carbon in the water samples were determined with a total organic carbon analyzer (Beckman Model 915-B).

The photosynthetic rate $\left(P_{v} ; \mathrm{gC} \cdot \mathrm{m}^{-3} \cdot \mathrm{hr}^{-1}\right)$ was calculated as follows (HAMA et al., 1983) :

$$
P_{v}=B\left(a_{2}-a_{0}\right) / t_{1}\left(a_{1}-a_{0}\right) \cdots \cdots \cdots \cdots \cdots \cdots(1)
$$

where $t_{1}$ is the duration of incubation (hour), $B$ is the POC $\left(B ; \mathrm{gC} \cdot \mathrm{m}^{-3}\right)$ at the end of the incubation, $a_{2}$ is the atom $\%$ of ${ }^{13} \mathrm{C}$ in the POC of the incubated sample, $a_{t}$ is the atom $\%$ of ${ }^{13} \mathrm{C}$ in the total inorganic carbon at the start of the incubation, and $a_{0}$ is the atom $\%$ of ${ }^{13} \mathrm{C}$ in the POC of natural sample.

For measurement of the respiration rate $\left(R_{V} ; \mathrm{gC}\right.$ $\cdot \mathrm{m}^{-3} \cdot \mathrm{hr}^{-1}$ ) of phytoplankton, the lake water was put into dark BOD bottles and incubated for $24 \mathrm{hr}$ at in situ water temperature. Dissolved oxygen was analyzed by azide modification of the Winkler method (APHA, 1980). The photosynthetic quotient was 1.05 (TAKAMURA et al., 1984). The respiration rate $\left(R_{c} ; \mathrm{gC} \cdot \mathrm{gC}^{-1} \cdot \mathrm{hr}^{-1}\right)$ and the net photosynthetic rate $\left(P ; \mathrm{gC} \cdot \mathrm{gC}^{-1} \cdot \mathrm{hr}^{-1}\right)$ were obtained by dividing $R_{V}$ 
and $P_{V}$ by POC $\left(B ; \mathrm{gC} \cdot \mathrm{m}^{-3}\right)$, respectively. The gross photosynthesis $\left(P_{g} ; \mathrm{gC} \cdot \mathrm{gC}^{-1} \cdot \mathrm{hr}^{-1}\right)$ was expressed by the sum of $P$ and $R_{C}$.

\section{$3-3-2$. Calculation of daily primary production} per unit area

When algae are exposed to a strong light irradiation, the photosynthesis-light curve may show a depression in photosynthetic rate, the so-called 'photoinhibition'. According to IWAKUMA and YASUNO (1983), the photosynthesis $\left(P_{\mathrm{g}}: \mathrm{gC} \cdot \mathrm{gC}^{-1} \cdot \mathrm{hr}^{-1}\right)$ of phytoplankton of Lake Kasumigaura showed photoinhibition in winter and fitted well the VoLLENWEIDER's formula (1965),

$$
P_{\mathrm{g}}=P_{o} I / I_{k o}\left(1+\left(I / I_{k o}\right)^{2}\right)^{-m}
$$

and photosynthesis-light curves from spring to autumn showed a light saturated ones which fitted well the SMiTH's formula (1936),

$$
P_{8}=P_{\max } I / I_{k}\left(1+\left(I / I_{k}\right)^{2}\right)^{-0.5} \quad \cdots \cdots \cdots \cdots \cdot(3)
$$

where $P_{0}$ is the potential value of maximum photosynthetic rate $\left(\mathrm{gC} \cdot \mathrm{gC}^{-1} \cdot \mathrm{hr}^{-1}\right), I_{k o}$ is the light intensity $\left(\mu\right.$ Einst. $\left.\mathrm{m}^{-2} \cdot \mathrm{s}^{-1}\right)$ at the junction of initial slope of photosynthesis-light curve and the $P_{o}, m$ is aparameter for photoinhibition (dimensionless, $>0.5$ ), $P_{\max }$ is the maximum rate of photosynthesis ( $\mathrm{gC}$. $\mathrm{gC}^{-1} \cdot \mathrm{hr}^{-1}$ ), and $I_{k}$ is the light intensity ( $\mu$ Einst. $\left.\mathrm{m}^{-2} \cdot \mathrm{s}^{-1}\right)$ at the junction of the initial slope of the photosynthesis-light curve and $P_{\max }$. Each parameter, $P_{o}, P_{\max }$, and the initial slope of the photosynthesis-light curve $\left(P_{o} / I_{k o}\right.$ or $P_{\max } / I_{k}:\left(\mathrm{gC} \cdot \mathrm{gC}^{-1}\right.$. $\left.\mathrm{hr}^{-1}\right)\left(\mu \text { Einst. } \mathrm{m}^{-2} \cdot \mathrm{s}^{-1}\right)^{-1}$ were determined by the nonlinear least square method.

Phytoplankton was assumed to be homogeneously distributed. The photosynthetic rate per unit area at the time $t\left(P z(t): \mathrm{gC} \cdot \mathrm{m}^{-2} \cdot \mathrm{hr}^{-1}\right)$ from spring to autumn, when the photoinhibition was not observed, was calulated by the Method 1 described in TAKAMURA et al. (1986).

The photosynthetic rate per unit area at the time $t\left(P_{z}(t) ; \mathrm{gC} \cdot \mathrm{m}^{-2} \cdot \mathrm{hr}^{-1}\right)$ in winter, when the photoinhibition was observed, was integrated numerically since Eq. (2) cannot be solved.

The gross production per unit area per day $\left(\mathrm{gC} \cdot \mathrm{m}^{-2} \cdot \mathrm{d}^{-1}\right)$ was calculated by the Method 1 as shown in TAKAMURA et al. (1986), and the monthly or yearly primary production were obtained by the Method 2 in TAKAMURA et al. (1986).

\section{Seasonal changes in main species biomass}

Microcystis was the most prominent alga in Takahamairi Bay (Sta. 3) with its large biomass (approx. 5-8 $\mathrm{gC} \cdot \mathrm{m}^{-3}$ ) occurred for a prolonged period (July-October). Anabaena flos-aquae appeared only at the early stage of the bloom of Microcystis. Exceptionally, Oscillatoria agardhii bloomed $\left(3-7 \mathrm{gC} \cdot \mathrm{m}^{-3}\right)$ from October to December 1982 and in April 1983.

The diatoms usually dominated in spring and autumn. Both Synedra rumpens and $S$. acus composed the spring peak. Melosira was observed for 5-6 months in the second half of the year, although the biomass did not become large. Coscinodiscus lacustris increased in autumn and winter and Cyclotella spp. in spring and winter.

The biomass of green algae was always small throughout the study period except for a large bloom of Closterium aciculare in spring of 1979. Chrysochromulina sp. (Chrysophyceae) increased only from January to April of 1980. Cryptomonas spp. (Cryptophyceae) increased in February and March 1981, in June 1982, and in June and July 1985. The maximum values of the biomass of these two classes were only $2 \mathrm{gC} \cdot \mathrm{m}^{-3}$.

The pattern of the seasonal changes of the main species at the center of the main basin (Sta. 9) was similar to that at Sta. 3. However, the biomass of Microcystis was usually small $\left(<2 \mathrm{gC} \cdot \mathrm{m}^{-3}\right)$ except in 1982 and 1984. Anabaena and Aphanizomenon tended to appear at the early or late stage of the Microcystis bloom. Large blooms of Oscillatoria agardhii and Closterium aciculare were also found at Sta. 9. The spring peak of diatom was always smaller than that at Sta. 3.

The seasonal changes in the biomass of the main species of phytoplankton at both stations are shown in the figures of the appendix.

\section{Seasonal changes in primary productivity}

\section{5-1. Environmental conditions and chlorophyll $a$}

The water temperature became more than $20^{\circ} \mathrm{C}$ from mid-May to mid-October, exceeded $30^{\circ} \mathrm{C}$ from late July to early September, and fell below $10^{\circ} \mathrm{C}$ from December to mid-March. The maximum value of daily solar radiation was usually recorded in May. The radiation once descended in the rainy season (from June to early July), but ascended again after then. The minimum value was usually observed in November.

The pattern of changes in the chlorophyll $a$ concentration varied considerably year by year or 

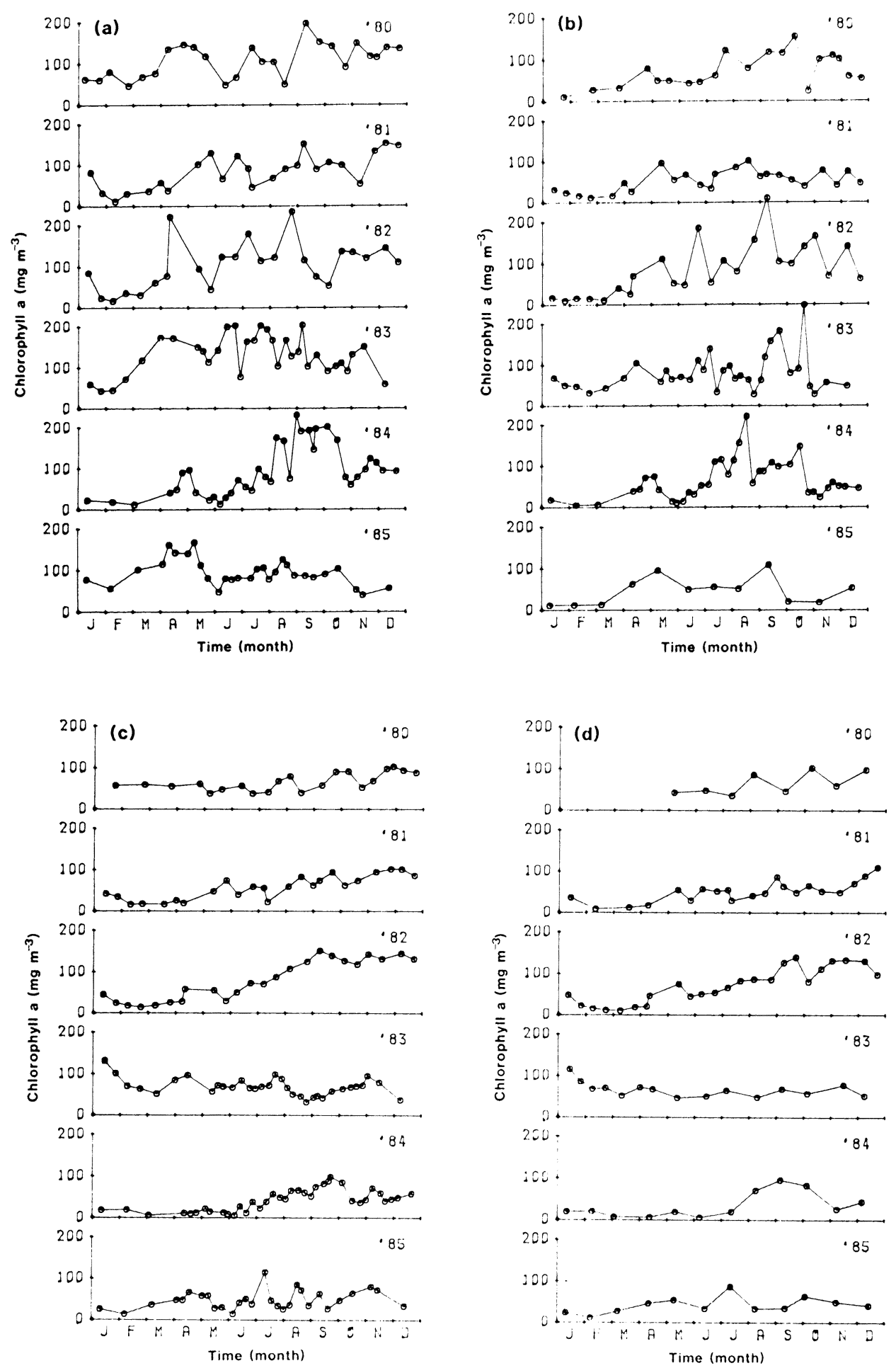

Fig. 2. Seasonal changes in the chlorophyll $a$ concentrations of water samples at Sta. 3 (a), Sta. 7 (b), Sta. 9(c) and Sta. 12(d). 
station by station (Fig. 2). The chlorophyll a concentration often exceeded $200 \mathrm{mg} \cdot \mathrm{m}^{-3}$ and varied largely both at Sta. 3 and Sta. 7 in the bays, as compared with that at Sta. 9 and Sta. 12 in the main basin. Generally, it was low during January to March and high during May to October. The chlorophyll a concentration was positively correlated with the water temperature at Stas. $3 \quad(n=79, r$ $=0.368)$ and $7(n=79, \quad r=0.515)$, but was not at Stas. 9 and 12. The chlorophyll $a$ concentration was negatively correlated with the solar radiation at Stas. $9(n=79, \quad r=-0.326)$ and $12(n=70, \quad r=-0$. 262 ) in the main basin, although it was not at Stas. 3 and 7 .

\section{5-2. Photosynthesis and primary production}

The photosynthesis-light curves in the most months were light-saturated ones, while photoinhibition was observed from January to early March. Figure 3 shows the seasonal changes in the initial slopes of the photosynthesis-light curves. The values of the slopes ranged mostly $0.2-0.5$ (mgC. $\left.\mathrm{gC}^{-1} \cdot \mathrm{hr}^{-1}\right)\left(\mu \text { Einst. } \mathrm{m}^{-2} \cdot \mathrm{s}^{-1}\right)^{-1}$ from April to November or December, and became low in winter. Since the $P_{\max }$ values were low in winter as shown below, the photosynthetic activity remained low under both low and high light intensities in winter. Consequently, the initial slopes were positively correlated with the maximum photosynthetic rates $\left(P_{\text {max }}\right)(n=48, r=0.500$ at Sta. 3 and $n=48, r=0.406$ at Sta. 9). The prominently high values of slopes were found in November 1982 and in June 1984, when Oscillatoria agardhii and Microcystis began to increase, respectively. Such high efficiency of photosynthesis under low light intensity might be an important sign which caused a large bloom.

Figure 4(a)-(d) shows the seasonal changes in the maximum photosynthetic rate $\left(P_{\max }\right)$ at four stations. The maximum value $\left(0.080-0.135 \mathrm{gC} \cdot \mathrm{gC}^{-1} \cdot \mathrm{hr}^{-1}\right)$ from 1981 to 1985 was generally recorded during June to September, when Microcystis bloomed, and the minimum value $\left(0.007-0.020 \mathrm{gC} \cdot \mathrm{gC}^{-1} \cdot \mathrm{hr}^{-1}\right)$ was recorded during January to March at each station. The exceptionally high values $(0.13$ and 0.15 $\mathrm{gC} \cdot \mathrm{gC}^{-1} \cdot \mathrm{hr}^{-1}$ ) were observed in the early November of 1982 at Stas. 3 and 9, when Oscillatoria began to increase. $P_{\max }$ was positively correlated with the water temperature at all stations $(n=48 r=0.600$ at Sta. 3, $n=70 r=0.707$ at Sta. $7, n=77 r=0.582$ at Sta. 9, and $n=65 r=0.726$ at Sta. 12 , respectively).

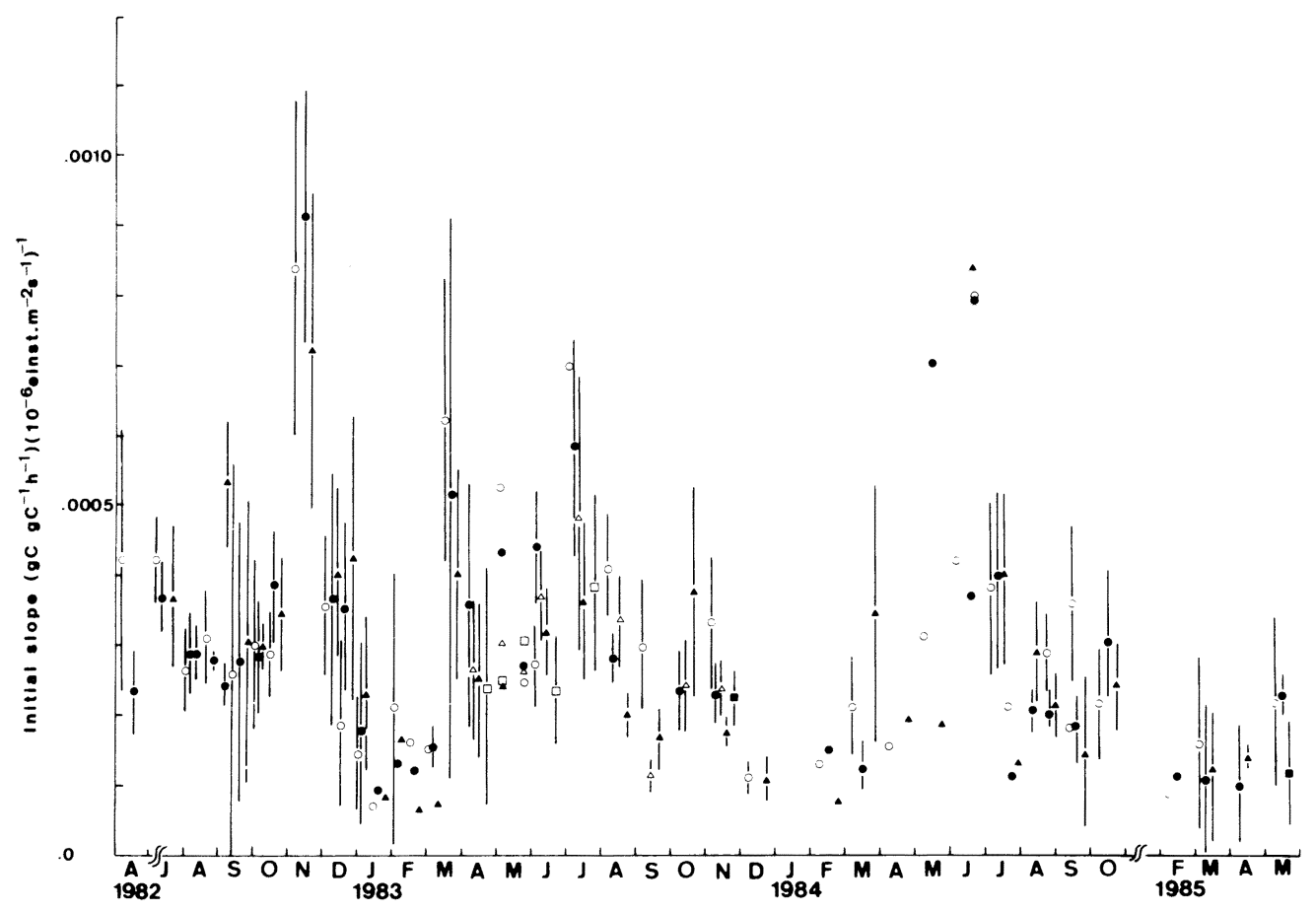

Fig. 3. Seasonal changes in the initial slopes of photosynthesis-light curves (open circle, Sta. 2; closed circle, Sta. 3 ; open triangle, Sta. 7 ; closed triangle, Sta. 9 ; closed square, Sta. 12). Bars indicate S. D. 

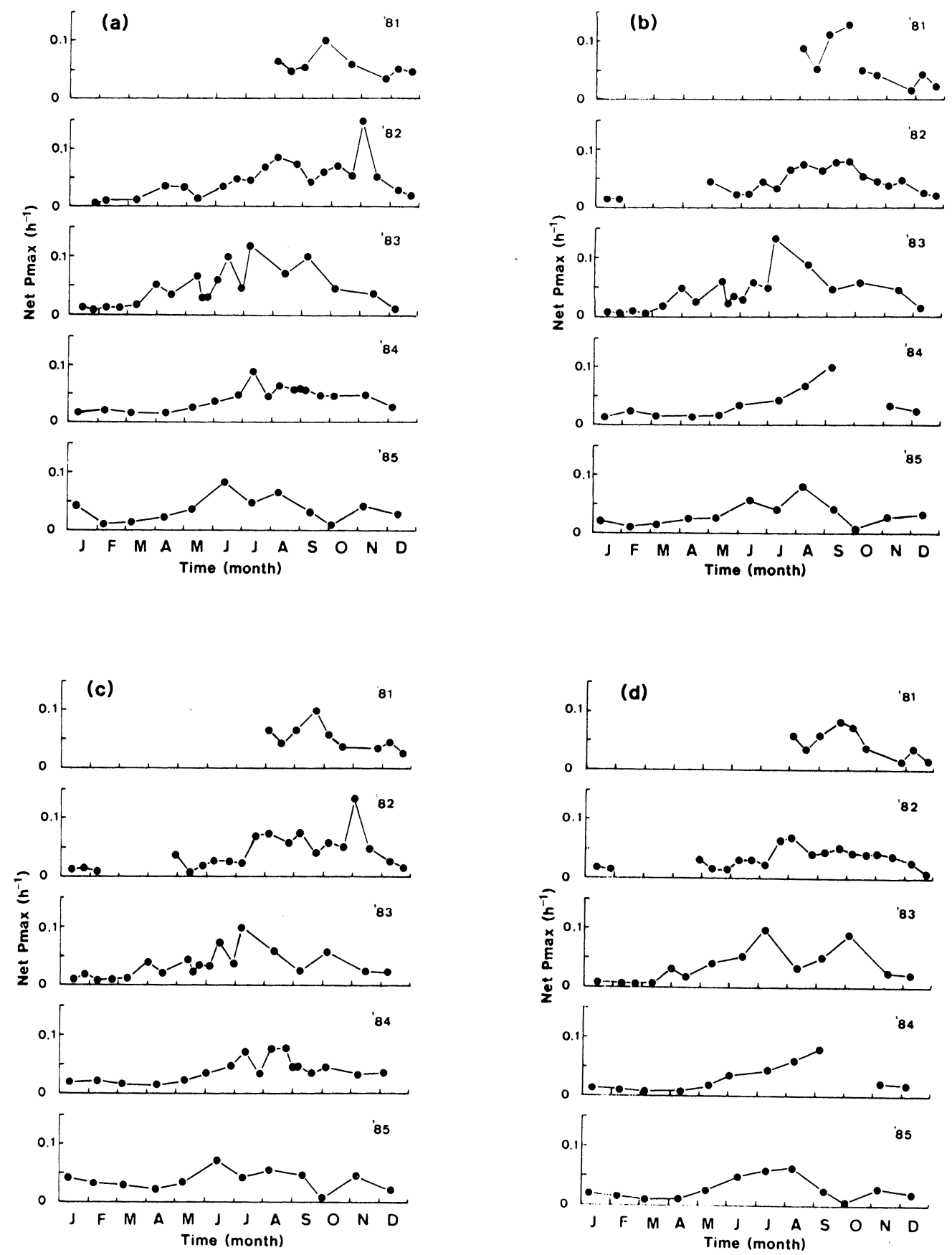

Fig. 4. Seasonal changes in the maximum rate of net photosynthesis at Sta. 3 (a), Sta. 7 (b), Sta. 9 (c), and Sta. 12 (d). 
The community respiration rates are shown in Figure 5 (a)-(d). These values were also high during May to September and low during December to
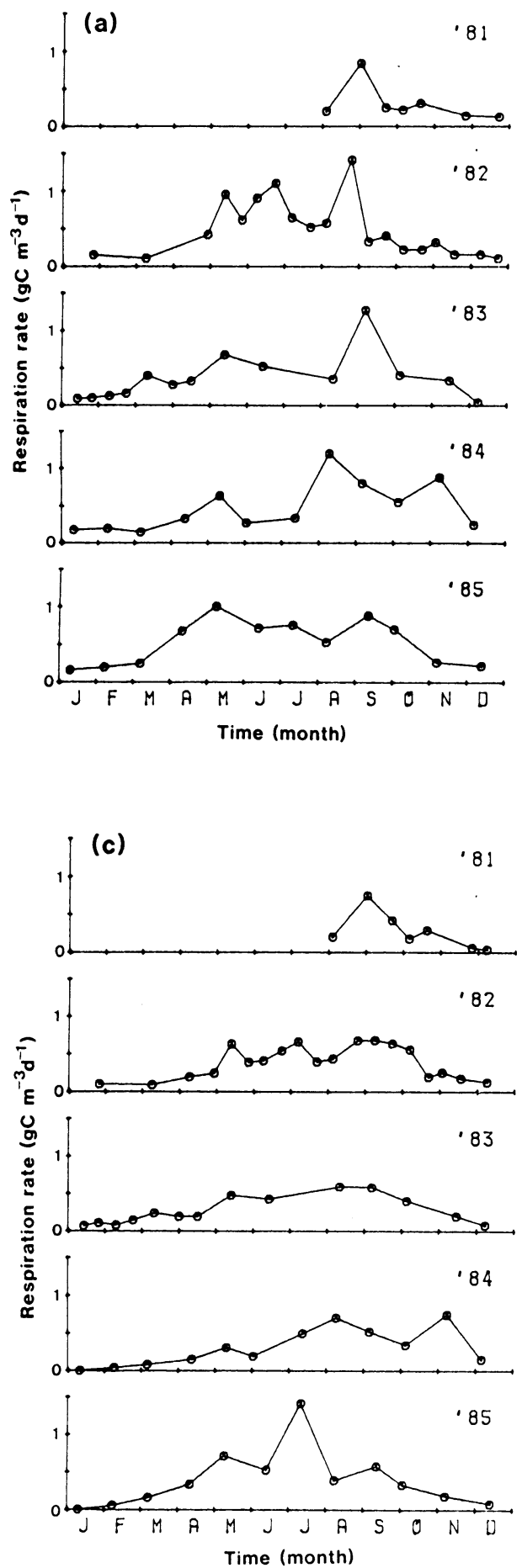

February at all stations. The maximum value from 1981 to 1985 ranged $0.592-1.415 \mathrm{gC} \cdot \mathrm{m}^{-3} \cdot \mathrm{d}^{-1}$, and the minimum value ranged $0.001-0.153 \mathrm{gC} \cdot \mathrm{m}^{-3} \cdot \mathrm{d}^{-1}$.

(b)

$\cdot 81$

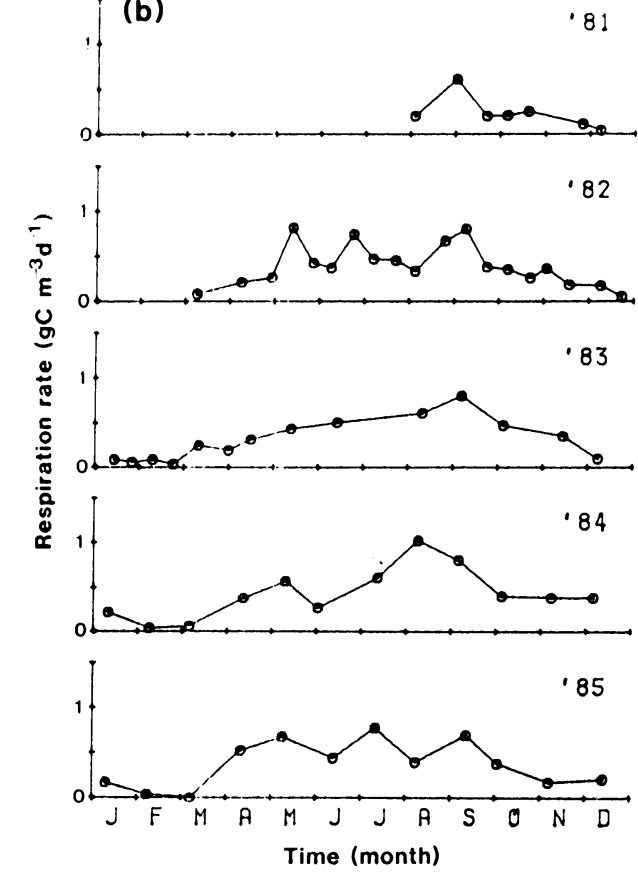

(d)

81

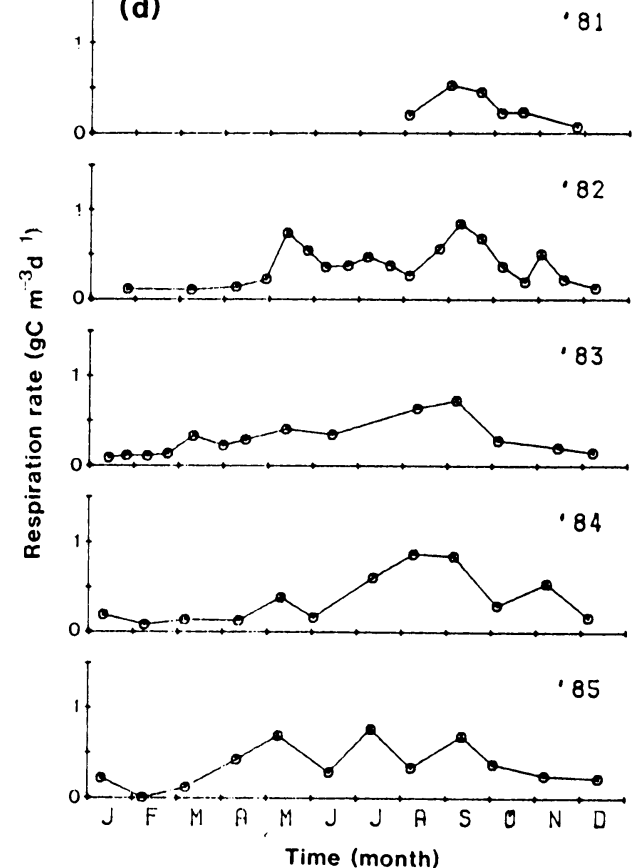

Fig. 5. Seasonal changes in the respiration rate at Sta. 3 (a), Sta. 7 (b), Sta. 9 (c), and Sta. 12 (d). 
The daily gross primary production was usually high during May to September and low in the other months, although it was exceptionally high in November 1982 as shown in Figure 6(a)-(d). The highest value was usually recorded in August, when Microcystis dominated. The maximum value from 1981 to 1985 at Sta. 3 ranged from 3.94 to $9.54 \mathrm{gC} \cdot \mathrm{m}^{-2} \cdot \mathrm{d}^{-1}$ and was higher than at the other stations. The productivity in summer of 1985 at Stas. 7,9 and 12 was smaller than in other years. The minimum value from 1981 to 1985 ranged from 0.16 to $0.87 \mathrm{gC} \cdot \mathrm{m}^{-2} \cdot \mathrm{d}^{-1}$. The gross production was highly correlated with water temperature, and negatively with dissolved inorganic nitrogen at all stations.

Figure 7 shows the changes in the monthly gross primary production. The high production values were usually recorded in summer, but the highest value was sometimes observed in May such as at Sta. 3 of 1985 and at Sta. 9 of both 1983 and 1985, and in October such as at Sta. 9 of 1982. The annual primary production was the highest at Sta. 3 every year except 1982, when Oscillatoria bloomed at Sta. 9. The summer production was lower in 1985 than in the other years because of the small biomass of Microcystis. It could be said that the values of gross primary production in 1981-1985 were similar to those in 1972-1979 (TEZUKA et al., 19731975 ; IWAKUMA and YASUNO, 1981), although the strict comparison between these studies was difficult because of the different methods.

\section{5-3. Relationship between primary production and environmental factors}

Table 1 shows the matrix of partial correlation coefficients (stepwise regression analysis) between the variables or parameters concerning primary production and environmental factors. Gross production $(G P)$ was correlated with solar radiation $(I o)$, water temperature (WT), and chlorophyll $a$ concentration (Chl. a), and was not correlated with nutrient concentrations at every station. The correlation coefficient between $G P$ and Chl.a was higher at Stas. 3 and 7 in the bays than at Stas. 9 and 12 in the main basin. Respiration (Res) was correlated with the same three factors at Stas. 3 and 7 , but was correlated with only water temperature $(W T)$ at Stas. 9 and 12. The coefficients of net production $(N P)$ varied considerably from station to station. $P_{\max }$ was correlated with $W T$ significantly. No variables concerning primary production were correlated with nutrient concentrations, and so nutrient was not a limiting factor for primary production in Lake Kasumigaura.

The multiple regression equations to express $G P$, Res, and $P_{\max }$ at each station are shown in Table 2 . The multiple correlation coefficient is indicated with $r$. More than $60 \%$ of gross production was contributed by solar radiation, water temperature. and chlorophyll $a$ concentration at all stations. On the other hand, respiration and $P_{\max }$ were determined mainly by water temperature.

\section{Characteristics of primary production in Lake Kasumigaura}

Generally, the primary production is controlled by 1) environmental conditions such as water temperature, solar radiation, and nutrient concentrations, 2) the biomass of phytoplankton, and 3) the photosynthetic potential of phytoplankton species. The values of primary production measured in 1956-1957 (ICHIMURA, 1958, 1960a,b, 1961 ; ICHIMURA, and ARUGA, 1958) was one sixth to one seventh of the present values because of the smaller biomass and the lower photosynthetic rate of phytoplankton. The $P_{\max }$ values of phytoplankton dominated by Microcystis were 7 to $8 \mathrm{gO}_{2} \cdot \mathrm{gchl}^{-1} \cdot \mathrm{hr}^{-1}$ (ICHIMURA, 1958 ; ICHIMURA and ARUGA, 1958), which were one half to one third of the values of Microcystis measured in the summer of 1981-1982 (TAKAMURA et al., 1985). The higher photosynthetic rates in recent years are ascribable to the increasing nutrient concentrations in the water.

IWAKUMA and YASUNO (1981) showed that the primary production of Lake Kasumigaura in 1979 was correlated with both the water temperature and the solar radiation, but was not correlated with chlorophyll a concentration, possibly because of too high chlorophyll a concentrations as the measurements were mostly carried out in the innermost Takahamairi Bay. However, it was correlated with the chlorophyll $a$ concentrations in addition to water temperature and solar radiation from 1981-1985 in the present study. This would reflect a hyperbolic relationship between the chlorophyll $a$ concentrations per unit volume and the primary production per unit area, because of the light limitations imposed by self-shading at high algal densities. Thus, the primary production of Lake Kasumigaura in recent years might approach the upper limit.

The primary production in autumn was lower than in spring and summer. However, it was exceptionally high in October of 1982, when Oscillatoria 


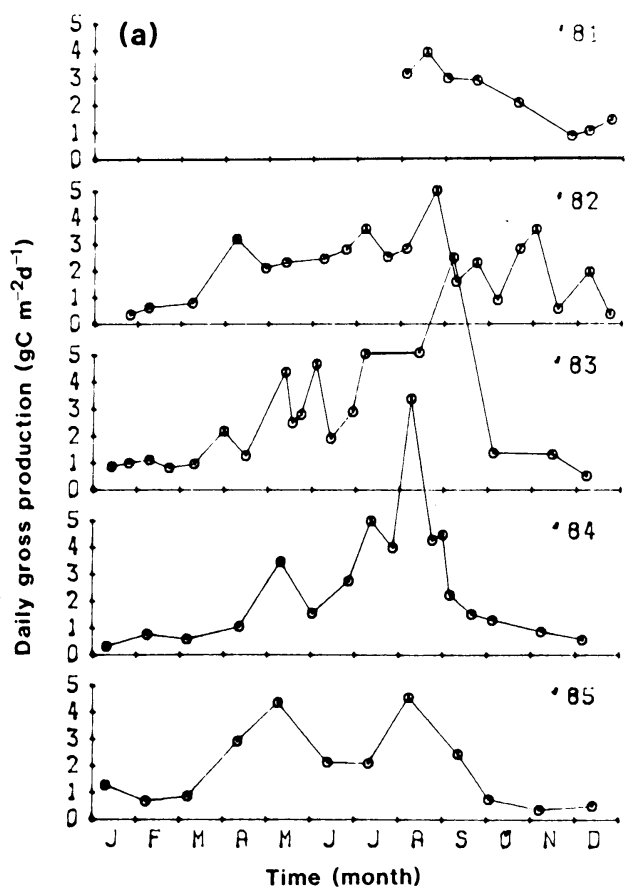

(b)

$\cdot 3$ i
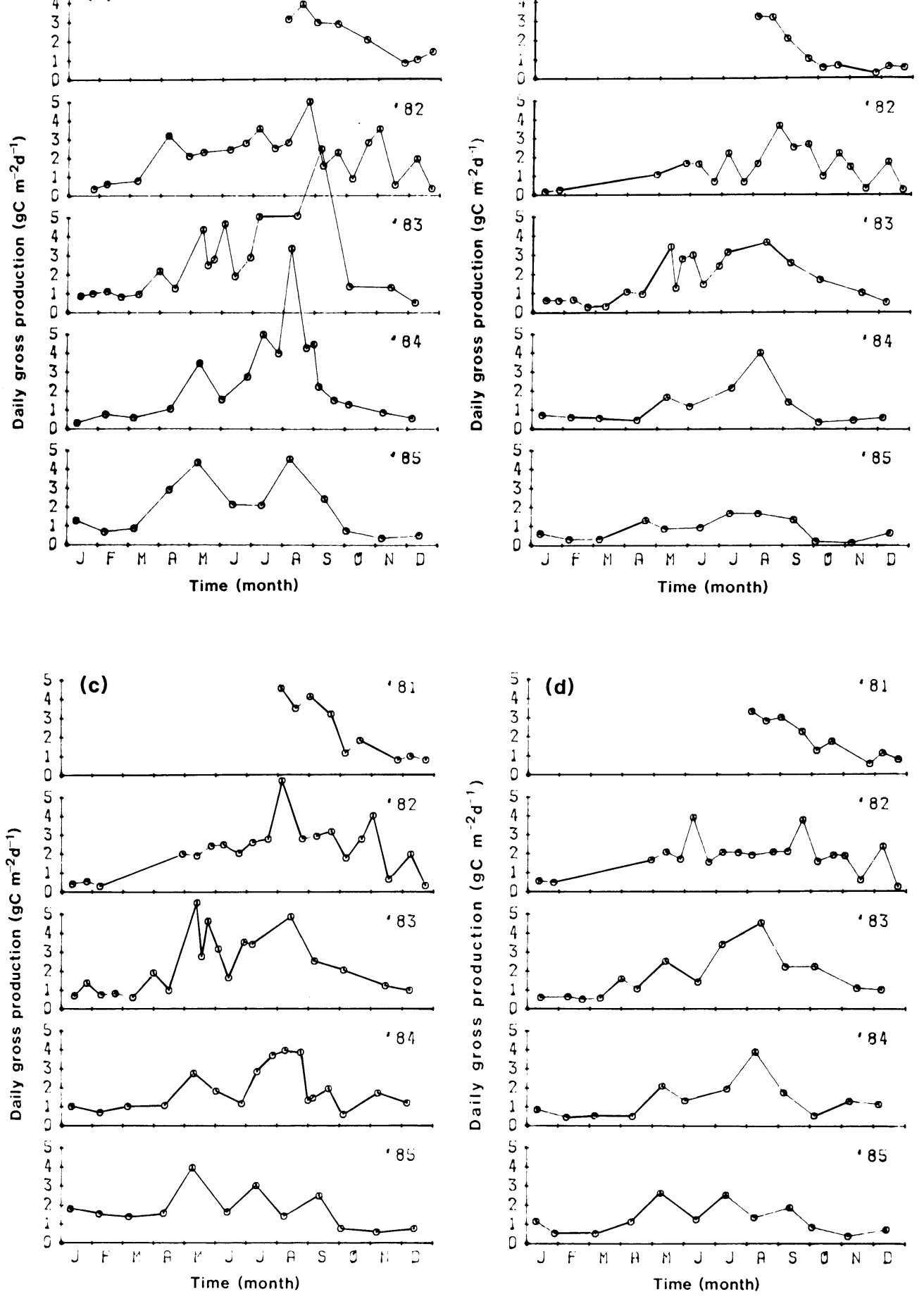

Fig. 6. Seasonal changes in the daily gross primary production at Sta. 3 (a), Sta. 7 (b), Sta. 9 (c), and Sta. 12 (d). 


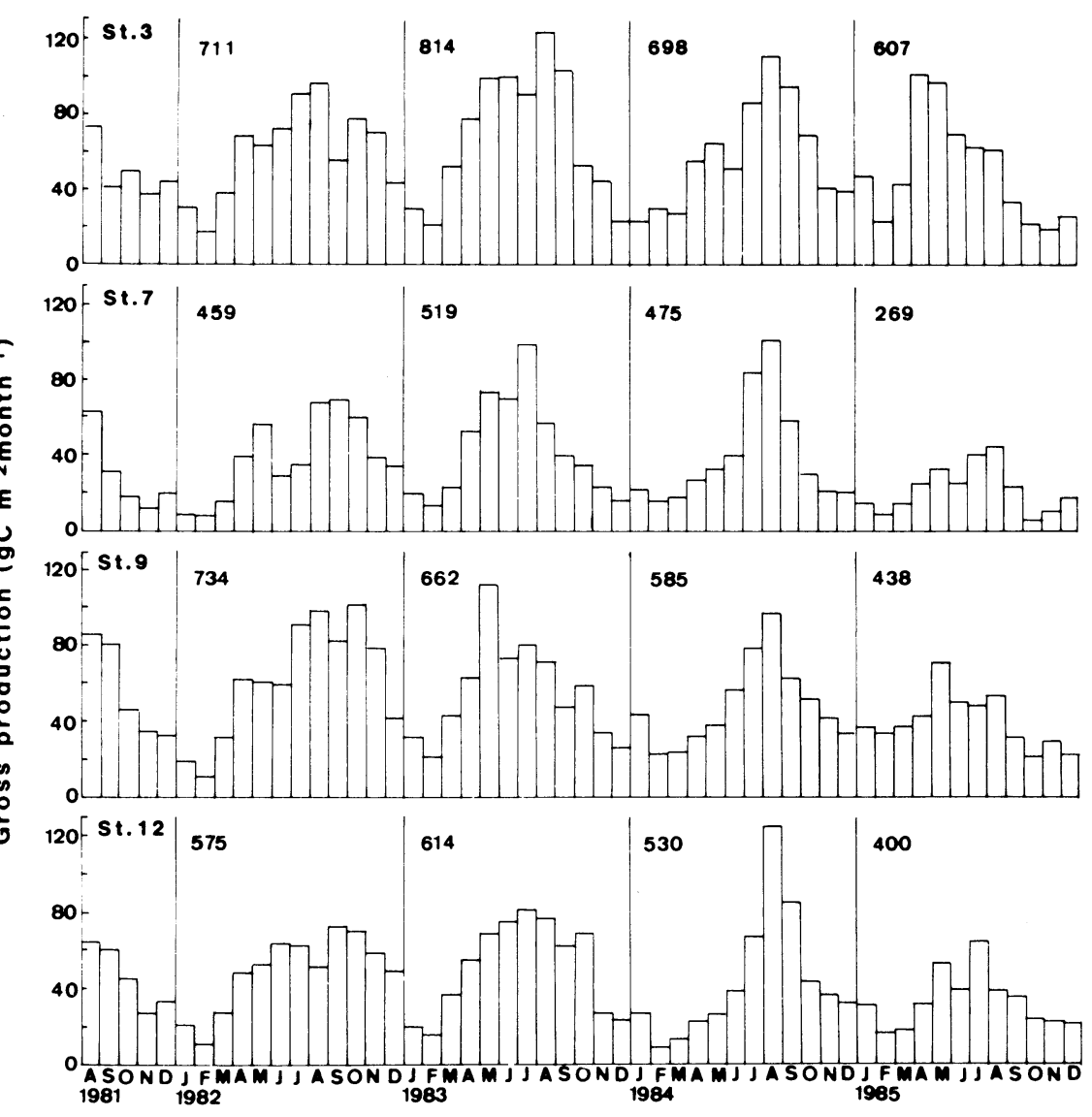

Fig. 7. Seasonal changes in the monthly gross primary production at each station. The number is the annual production of each year.

agardhii bloomed. This high primary production would be explained by the prominently high $P_{\max }$ of $O$. agardhii in addition to its high biomass. The similar high production attributed to a high photosynthetic rate was observed in spring 1979 (IwAKUMA and YASUNO, 1981), when Closterium aciculare bloomed. Therefore, the photosynthetic activity of some specific species would become important to determine the primary production.

\section{Characteristics of lakes with the bloom of Microcystis.}

According to boundary values of some variables for trophic categories of hypertrophic (OECD, 1982) i.e., the mean annual total phosphorus $>100$ $\mathrm{mg} \cdot \mathrm{m}^{-3}$, mean annual euphotic chlorophyll $a>25$ $\mathrm{mg} \cdot \mathrm{m}^{-3}$, annual peak chlorophyll $a>75 \mathrm{mg} \cdot \mathrm{m}^{-3}$, mean annual Secchi disc transparency $<1.5 \mathrm{~m}$, and/or minimum value of Secchi disc transparency
$<0.7 \mathrm{~m}$, Microcystis is the most common alga which appears in many shallow hypertrophic lakes in the world $\left(57^{\circ} \mathrm{N}-31^{\circ} \mathrm{S}\right)$ as shown in Table 3 . The primary productivity in such lakes was in high range of $3-13 \mathrm{gC} \cdot \mathrm{m}^{-2} \cdot \mathrm{d}^{-1}$ or $300-1,800 \mathrm{gC} \cdot \mathrm{m}^{-2} \cdot \mathrm{yr}^{-1}$.

Microcystis seems to dominate in the lakes with annual primary production higher than approx. 300 $\mathrm{gC} \cdot \mathrm{m}^{-2}$. Lake Dong Hu or Lake Mendota is situated at this boundary. Microcystis tends to be the sole dominant species in lakes situated at the low latitude, but Microcystis tends to coexist with Anabaena and/or Aphanizomenon in lakes situated at the high latitude.

In general, yearly primary production was significantly correlated with annual average total phosphorus concentration and annual average chlorophyll a concentration, on a log-log linear scale (OECD, 1982). However, there are some exceptions. In the case of Lake Myvatn and Lake Esrom, the 
Table 1 Matrix of partial correlation coefficients between the variables or parameters concerning primary production and environmental factors at Sta. 3 (a), Sta. 7 (b), Sta. 9 (c), and Sta. 12 (d). The number of data set is shown in parenthesis. $G P$; gross production $\left(\mathrm{gC} \cdot \mathrm{m}^{-2} \cdot \mathrm{d}^{-1}\right), N P$; net production $\left(\mathrm{gC} \cdot \mathrm{m}^{-2} \cdot \mathrm{d}^{-1}\right)$, Res; community respiration rate $\left(\mathrm{gC} \cdot \mathrm{m}^{-3} \cdot \mathrm{d}^{-1}\right), P_{\max } ; P_{\max }\left(\mathrm{gC}_{\mathrm{gC}} \mathrm{gC}^{-1} \cdot \mathrm{hr}^{-1}\right)$, WT ; water temperature at the time of measurements $\left({ }^{\circ} \mathrm{C}\right), I O$; daily solar radiation at the sampling day (ly), Chl. $a$; chlorophyll a concentration $\left(\mathrm{mg} \cdot \mathrm{m}^{-3}\right), P O_{4}-P$; soluble reactine phosphorus $\left(\mathrm{g} \cdot \mathrm{m}^{-3}\right), D I N$; ammonium + nitrate + nitrite-nitrogen $\left(\mathrm{g} \cdot \mathrm{m}^{-3}\right)$

\begin{tabular}{|c|c|c|c|c|c|}
\hline (a) & Chl.a & $W T$ & Io & $\mathrm{PO}_{4}-\mathrm{P}$ & $D I N$ \\
\hline$G P(71)$ & $.459^{* *}$ & $.474^{* *}$ & $.496^{* *}$ & -.099 & .047 \\
\hline $\operatorname{Res}(58)$ & $.446^{* *}$ & $.592^{* *}$ & $.467^{* *}$ & -.205 & -.031 \\
\hline$N P(60)$ & .096 & .136 & .226 & -.043 & .020 \\
\hline$P_{\max }(45)$ & .214 & $.580^{* *}$ & -.133 & -.195 & .204 \\
\hline (b) & Chl.a & $W T$ & Io & $\mathrm{PO}_{4}-\mathrm{P}$ & $D I N$ \\
\hline$G P(66)$ & $.485^{* *}$ & $.358^{* *}$ & $.548^{* *}$ & .006 & .070 \\
\hline $\operatorname{Res}(63)$ & $.434^{* *}$ & $.615^{* *}$ & $.314^{*}$ & .166 & .141 \\
\hline$N P(60)$ & .183 & -.136 & $.339^{* *}$ & -.114 & -.36 \\
\hline$P_{\max }(66)$ & .087 & $.563^{* *}$ & -.066 & .137 & .116 \\
\hline (c) & Chl.a & $W T$ & Io & $P_{4}-P$ & $D I N$ \\
\hline$G P(72)$ & $.343^{* *}$ & $.446^{* *}$ & $.534^{* *}$ & -.058 & -.069 \\
\hline $\operatorname{Res}(66)$ & .161 & $.587^{* *}$ & .102 & -.073 & -.049 \\
\hline$N P(72)$ & .102 & $-.286^{*}$ & $.332^{* *}$ & .031 & -.014 \\
\hline$P_{\max }(72)$ & .158 & $.545^{* *}$ & -.192 & -.069 & .027 \\
\hline (d) & Chl.a & $W T$ & Io & $\mathrm{PO}_{4}-\mathrm{P}$ & $D I N$ \\
\hline$G P(65)$ & $.251^{*}$ & $.472^{* *}$ & $.475^{* *}$ & .068 & -.230 \\
\hline $\operatorname{Res}(63)$ & .202 & $.679^{* *}$ & .207 & $-.261^{*}$ & -.006 \\
\hline$N P(60)$ & .097 & $-.275^{*}$ & $.332^{*}$ & .205 & -.160 \\
\hline$P_{\max }(65)$ & .005 & $.593^{* *}$ & $-.392^{* *}$ & .195 & .061 \\
\hline
\end{tabular}

** Significant at 0.01 probability level

* Significant at 0.05 probability level

Table 2. The multiple regression equations to express GP, Res, and $P_{\max }$ at (a) Sta. 3, (b) Sta. 7, (c) Sta. 9, and (d) Sta. 12.
(a) $G P=-1.83+0.0114$ Chl.a $+0.0836 W T+0.00122 I o\left(r^{2}=0.66\right)$
(b) $G P=-0.771+0.0083$ Chl.a $+0.0373 W T+0.0007$ Io $\left(r^{2}=0.69\right)$
(c) $G P=-1.04+0.0104$ Chl.a $+0.0631 W T+0.0010$ Io $\left(r^{2}=0.62\right)$
(d) $G P=-0.556+0.0072$ Chl.a $+0.0616 W T+0.0005 I o\left(r^{2}=0.64\right)$

(a) Res $=-0.0142+0.0291 W T\left(r^{2}=0.53\right)$

(b) Res $=-0.0418+0.0242 W T\left(r^{2}=0.68\right)$

(c) Res $=-0.0278+0.0215 W T\left(r^{2}=0.52\right)$

(d) Res $=0.0002+0.0209 W T\left(r^{2}=0.59\right)$

(a) $P_{\max }=0.363+0.0469 W T\left(r^{2}=0.37\right)$

(b) $P_{\max }=0.120+0.0025 \mathrm{WT}\left(r^{2}=0.53\right)$

(c) $P_{\max }=0.352+0.0017 \mathrm{WT}\left(r^{2}=0.36\right)$

(d) $P_{\max }=0.254+0.0042 \mathrm{WT}\left(r^{2}=0.37\right)$ 


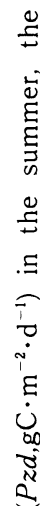

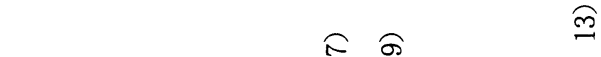

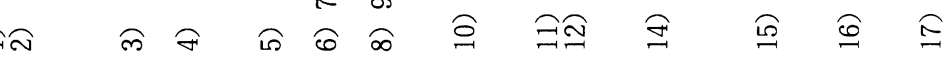

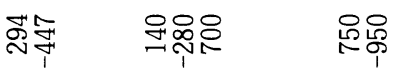

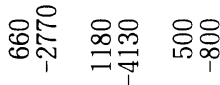

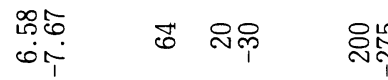

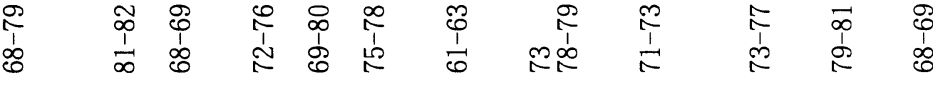

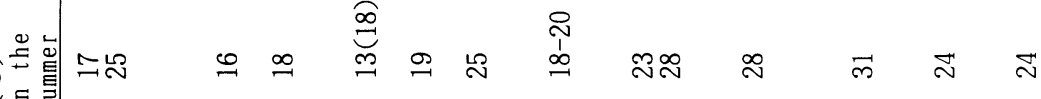

亲

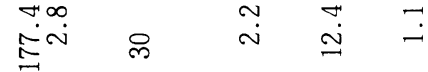

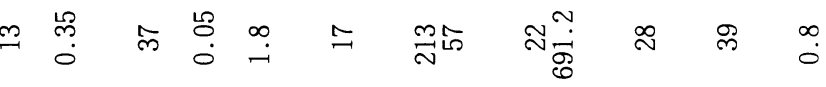

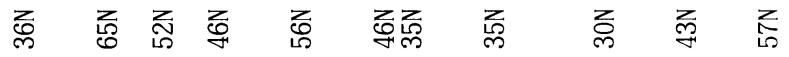

言害

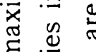

空

का

in

के

E

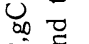

\&

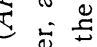

है है.

공 क

结

ชิ

E

ब

密

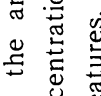

प응

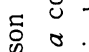

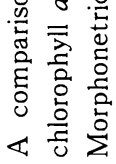

$\stackrel{\frac{\pi}{3}}{\frac{0}{2}}$

晶籿

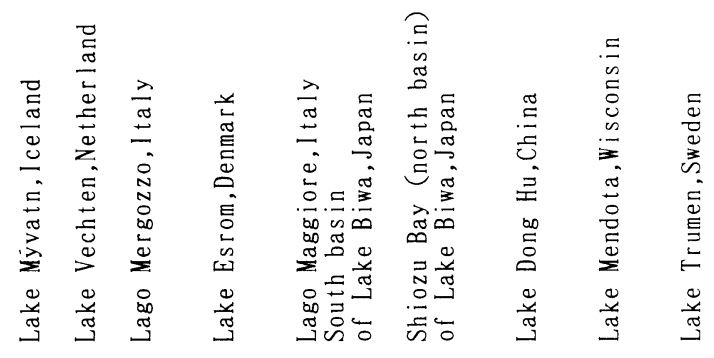

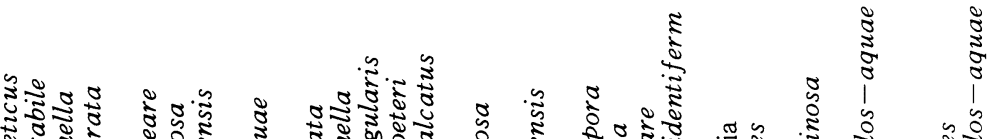

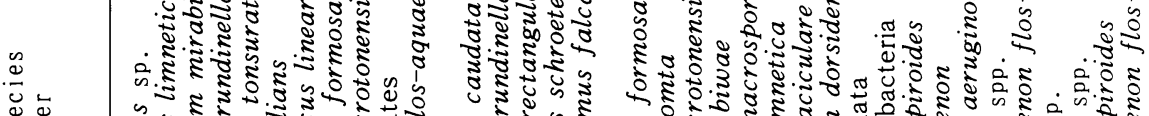

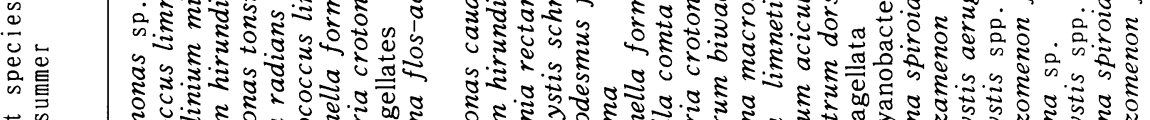

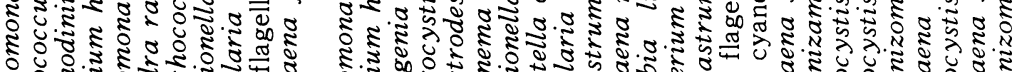

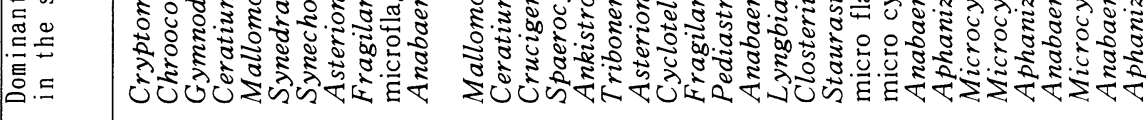

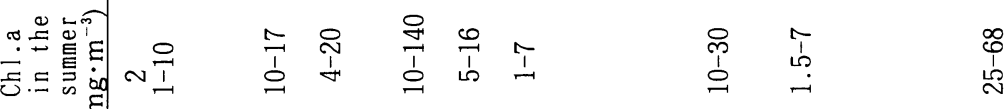

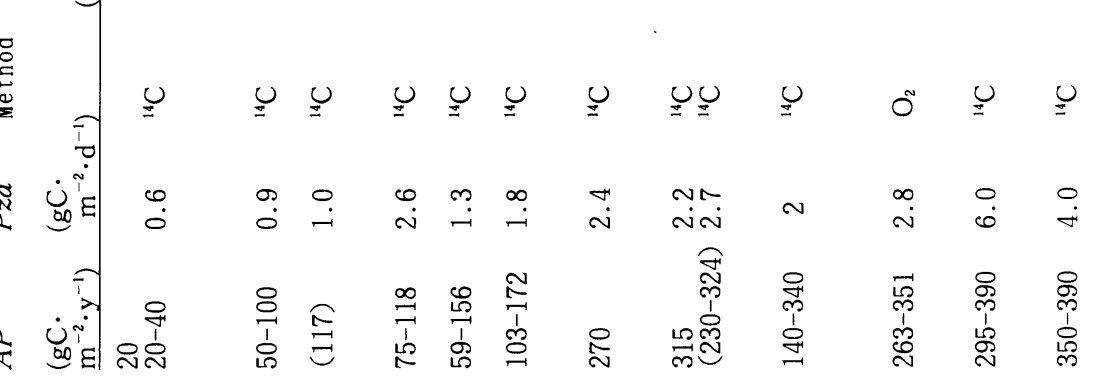




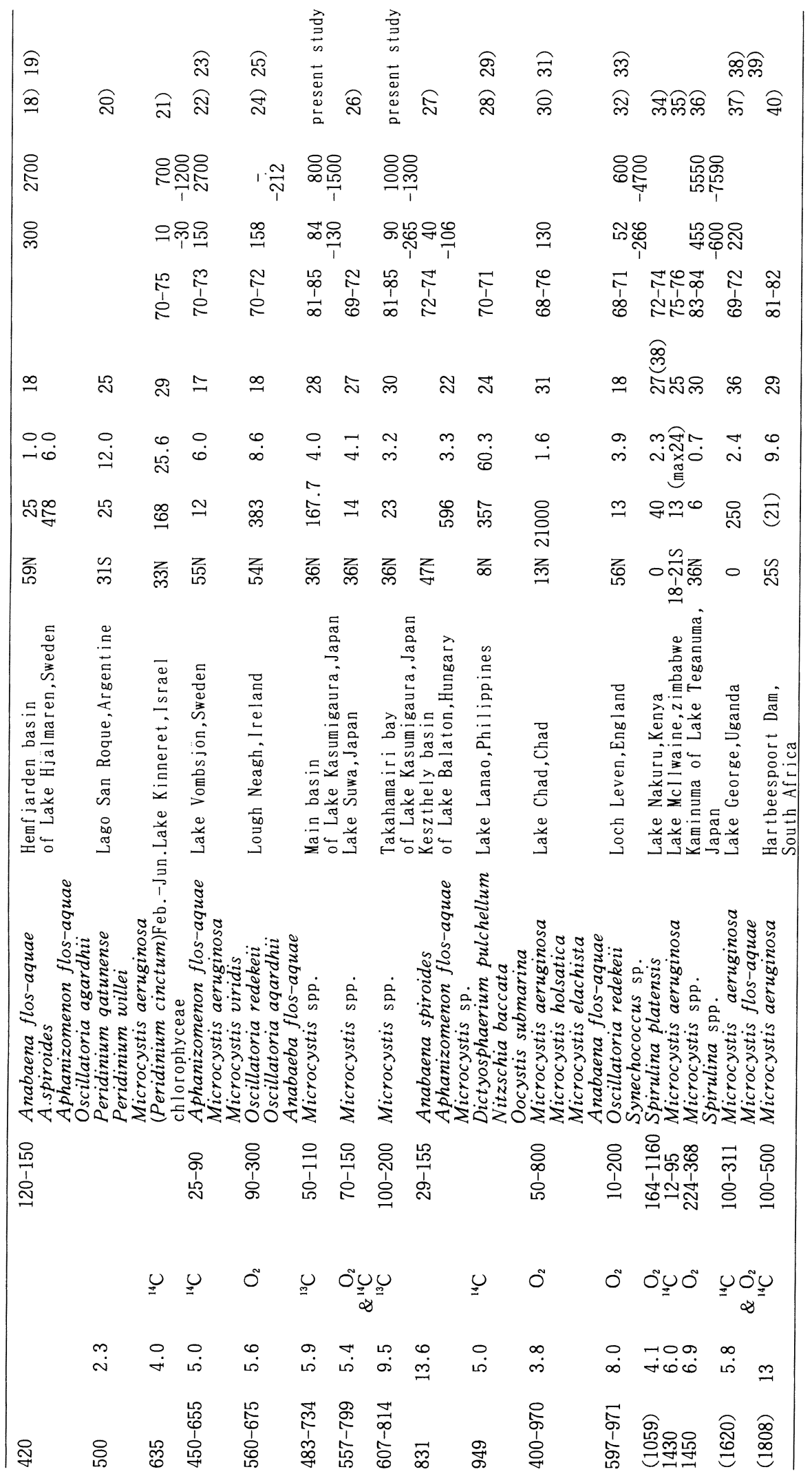




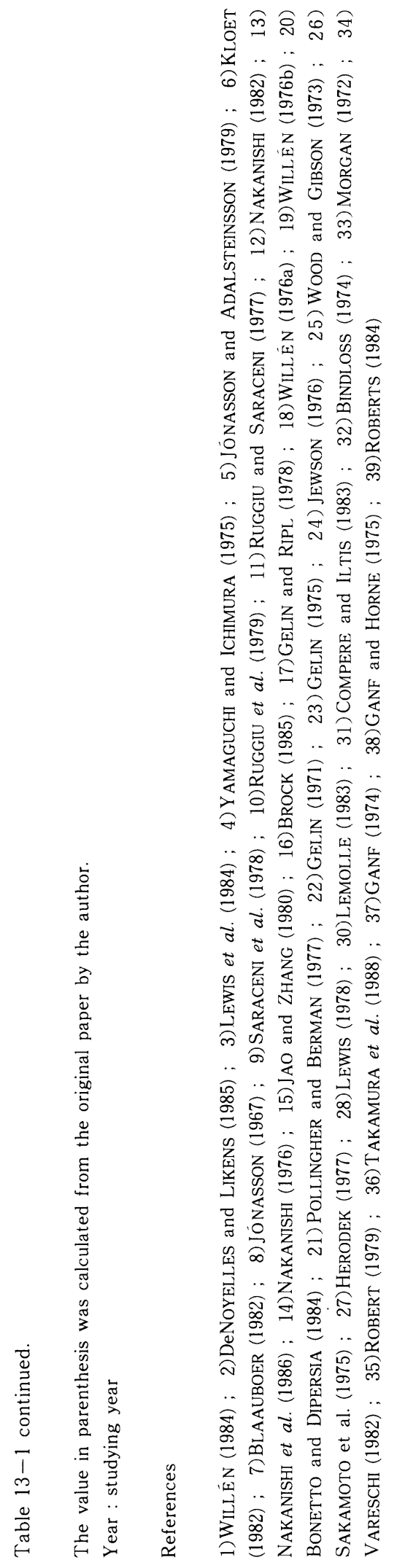


yearly primary production was low in spite of their high TP concentrations. Lake Esrom is apparently classified as a hypertrophic lake according to the OECD category (1982). Since the TN concentrations of these lakes were far lower than those other hypertrophic lakes with high primary productivity, nitrogen would limit the algal productivity in these lakes. On the contrary, in the case of Lake Kinneret and Lake Lanao, the yearly primary production was high in spite of their low TP concentrations. Lake Kinneret and Lake Lanao are classified as a mesotrophic lake according to the OECD category (1982), because both lakes have higher values of Secchi disc transparency, that is, $2-3.5 \mathrm{~m}$ in Lake Kinneret (BERMAN, 1978) and 3-8 $\mathrm{m}$ in Lake Lanao (calculated from LEWIS (1974)), and the total phosphorus concentrations of Lake Kinneret was as low as $10-30 \mathrm{mg} \cdot \mathrm{m}^{-3}$. Additionally, the two lakes were deeper than the other lakes with high productivity. Microcystis did not dominate in such exceptional lakes. The dominant algal taxon of the latter two lakes was chlorophyceae, which might fix more carbon per unit weight of phosphorus than cyanobacteria.

Microcystis did not necessarily dominate in every hypertrophic lakes with high primary productivity. Lake Nakuru is an alkaline lake ; in fact, Spirulina platensis is known to grow in hypersaline waters (HAMMER, 1986). The blooming genus in Loch Leven and Lough Neagh was Oscillatoria. The reason why Microcystis did not dominate in these lakes cannot be explained. However, the $\mathrm{PO}_{4}-\mathrm{P}$ increased and nitrate was depleted in the water during summer in lakes with the blooming of Microcystis, such as Lake Vombsjön, Lake Trummen and Lake Kasumigaura, whereas the $\mathrm{PO}_{4}-\mathrm{P}$ was depleted and considerable amounts of nitrate existed in the water of summer in Loch Leven and Lough Neagh. Probably, the nutrient demand of Oscillatoria would be different from that of Microcystis.

\section{Acknowledgments}

We thank Dr. A. Otsuki for providing the data on inorganic phosphorus and nitrogen concentrations and Dr. T. Hanazato for offering data on chlorophyll a concentrations in 1985. We also thank all members of the Survey Group of Lake Kasumigaura of the National Institute for Environmental Studies for their collaboration in the field work.

\section{摘 要}

\section{霞ヶ浦における一次生産量について}

1981年から1985年にかけて霞ヶ浦の 4 地点で基礎生 産量を測定した。総生産量と水温, 日射量, クロロ フィル a 量, 全無機態窒素, およびオルトリン酸の重 相関を調べたところ, ぞの地点でも水温, 日射量, お よびクロロフィル a 量と有意な相関を示したが, 栄養 塩とは示さなかった。したがって, 霞ヶ浦の総生産量 は栄養塩の制限をらけていないといえる。本湖では毎 年6月から7月に藍藻の Microcystis spp.が大発生し た。また，1979年の冬から春には緑藻のClosterium aciculare, 1982 年の秋から冬には藍藻のOscillatoria agardhii が大増殖したが, これらの時の光合成速度は 著しく高かった。湖心の年間総生産量は 483-734gC $\cdot \mathrm{m}^{-2} \cdot \mathrm{yr}^{-1}$ で，1970年代に測定された值と大きく変化 していなかった。一方，この值はMicrocystisが優占 する他の多くの湖の一次生産量の中臣の值であった。

\section{References}

APHA (1980): Standard Methods for the Examination of Water and Wastewater. 15th ed. 1134 pp. N.Y.American Public Health Association.

BERMAN, T. (1978) : Light penetration. P. 149-156. In C. SerruyA (ed.), Lake Kinneret, Junk Publishers.

Bindloss, M. E. (1974) : Primary productivity of phytoplankton in Loch Leven, Kinross. Proc. Roy. Soc. Edinb. (B)., $74: 157-181$.

BlaAuboer, M. C. I. (1982) : The phytoplankton species compostition and the seasonal periodicity in Lake Vechten from 1956 to 1979. Hydrobiologia, $95: 25-36$.

Bonetto, A. A. and D. H. DI Persia (1984): The San Roque reservoir and other man-made lakes in the central region of Argentina. p. 541-556. In E. B. TAUB (ed.), Lakes and Reservoirs. Elsevier science publishers B. V., Amsterdam.

BRocK, T. D. (1985) ; A Eutrophic Lake-Lake Mendota, Wisconsin. Springer-Verlag. p. 1 308.

COMPERE, P. and A. IITIS (1983) : The phytoplankton. P. 145-197. In J. P. CARMouze, J. R. Durand, and C. Leveque, C. (eds.) Lake Chad, Junk Publishers.

DeNoyelles, F. and G. E. Likens (1985) : Phytoplankton. p. 161-175 and pp 250-257. In G. E. LiKENs (ed.), An Ecosystem Approach to Aquatic Ecology. Springer-Verlag, New York. 
GANF, G. G. (1974) : Diurnal mixing and the vertical distribution of phytoplankton in a shallow equatorial lake (Lake Geroge, Uganda), J. Ecol., 62: 611-629.

GANF, G. G. and A. J. Horne (1975) : Diurnal stratification, photosynthesis and nitrogenfixation in a shallow, equatorial Lake (Lake George, Uganda). Freshwat. Biol., 5 : 13-39.

GANF, G. G. (1975) : Photosynthetic production and irradiance-photosynthesis relationships of the phytoplankton from a shallow equatorial Lake (Lake George, Uganda), Oecologia (Berl.), 18 : $165-183$

GeLiN, C. (1971) : Primary production and chlorophyll $a$ content of nanoplankton in a eutrophic lake. Oikos, 22 : 230-234.

Gelin, C. (1975) : Nutrients, biomass and primary productivity of nanoplankton in eutrophic Lake Vombsjön, Sweden. Oikos, $26: 121-139$.

Gelin, C. and G. RIPL (1978) : Nutrient decrease and response of various phytoplankton size fractions following the restoration of Lake Trummen, Sweden. Arch. Hydrobiol., 81 : 339-367.

Hama, T., T. Miyazaki, Y. Ogawa, T. IwaKuma, M. TAKAHASHI, A. OtSUKI and S. ICHIMURA (1983) : Measurement of photosynthetic production of marine phytoplankton population by using a stable ${ }^{13} \mathrm{C}$ isotope. Mar. Biol., 73 : $31-36$.

Hammar, U. H. (1986) : Saline Lake Ecosystems of the World, Junk Publishers. p.1-608.

HERODEK, S. (1977) : Recent results of phytoplankton research in Lake Balaton, Ann. Biol., Tihany, $44: 181-198$.

IBARAKI, PREFECTURE (1912) : Survey Report of Fishes in Lake Kasumigaura and Kitaura. pp. 259 (in Japanese).

ICHIMURA, S. (1958): On the photosynthesis of natural phytoplankton under field conditions. Bot. Mag. Tokyo, $71: 110-116$.

ICHIMURA, S. (1960a) : Diurnal fluctuation of chlorophyll content in lake water. Bot. Mag. Tokyo, $73: 217-224$.

ICHIMURA, S (1960b) : Photosynthesis pattern of natural phytoplankton relating to light intensity. Bot. Mag. Tokyo, $73: 869-870$.

ICHIMURA, S (1961): On the spatial difference of the primary production in the lake and its relation to environmental factors. Bot. Mag. Tokyo, 74 : $6-13$.

ICHIMURA, S. and Y. ARUGA (1958) : Some charac- teristics of photosynthesis of fresh water phytoplankton. Bot. Mag. Tokyo, 71 : $261-$ 269.

IwAKUMA, T. and M. AIZAKI (1979) : Primary production at Takahamairi Bay in Lake Kasumigaura : Seasonal and summer diurnal changes. Res. Rep. Natl. Inst. Environ. Stud., No. 6: 139-153 (in Japanese).

IwAKUMA. T. and M. YASUNo (1981) : Characteristics of primary production in Lake Kasumigaura. Res. Rep. Natl. Inst. Environ. Stud., No. 22 : 99-122 (in Japanese).

IWAKUMA, T. and M. YASUNO (1983) : A comparison of several mathematical equations describing photosynthesis-light curve for natural phytoplankton populations. Arch. Hydrobiol., 97 : $208-226$.

JAO, C. C. and Z. S. ZHANG (1980): Ecological changes of phytoplankton in Lake Dong $\mathrm{Hu}$, Wuhan, during 1956-1975 and the eutrophication problem. Acta Hydrobiol, Sinica, $7: 1-17$.

JEWson, D. H. (1976) : The interaction of components controlling net phytoplankton photosynthesis in a well-mixed lake (Lough Neagh, North Ireland). Fresh. Biol., 6 : 551-576.

JónAsson P. M. and J. Kristiansen (1967) : Primary and secondory production in Lake Esrom. Growth of Chironomus anthracinus in relation to seasonal cycles of phytoplankton and dissolved oxygen. Int. Revue ges. Hydrobiol., 52 : $163-217$.

JónAsson, P. M. and H. AdAlsteinsson (1979) : Phytoplankton production in shallow eutrophic Lake Mývatn, Iceland. Oikos, 32 : 113-138.

Kasebayashi, T., M. SunOU, and I. NAKano (1957) : Limnological Studies of Lake Kasumigaura and Kitaura (1955). Fishery center of Ibaraki Prefecture. $2: 11-19$ (in Japanese).

Kasebayashi, T., Sunou, and I. Nakano (1959a) : Limnological Studies of Lake Kasumigaura (1956). fishery office of Ibaraki Prefecture. 4 : 1-10 (in Japanese).

Kasebayashi, T., M. Sunou, I. Nakano and N. HASHTANI (1959b) : Limnological Studies of Lake Kasumigaura (1957). Fishery office of Ibaraki Prefecture. $4: 11-17$ (in Japanese).

Kloet, W. A. D. (1982) : Primary production of phytoplankton in Lake Vechten. Hydrobiologia, $95: 37-57$.

LEMOALle, J. (1983) : Phytoplankton production. p. 357-384. In J. P. CARMouze, J. R. Durand and 
C. LEVEQUE (eds.), Lake Chad, Junk publishers.

LEwIS, W. M. J. (1974) : Primary production in the plankton community of a tropical lake. Ecol. Monogr., $44: 377-409$.

LEWIS, W. M. J. (1978) : Dynamics and succession of the phytoplankton in a tropical lake: Lake Lanao, Philippines. J. Ecol., $66: 849-880$.

LewIS, W. M. J., J. F. S. SAunder, D. W. CRumpa CKER, and C. BRENDECKE (1984): Eutrophication and Land Use-Lake Dillon, Corolado. Springer-Verlag.

Maeda, O., S. Iwamoto and Y. Yamaguchi (1974) : Some consideration on eutrophication of Lake Kasumigaura. Jpn. J. Limnol., 35 : 53-59(in Japanese).

Morgan, N. C. (1972) : Productivity studies at Loch Leven (a shallow nutrient rich lowland lake). In Z. KAJAK and A. HILLBRICHT-ILKOWSKA (eds.), Proceedings of IBP-UNESCO Symposium on Productivity Problems of Freshwaters, pp. 183-205.

NAKANISHI, M. (1976) : Seasonal variation of chlorophyll $a$ amounts, photosynthesis and production rates of macro-and microphytoplankton in Shiozu Bay, Lake Biwa. Physiol. Ecol. Japan, $17: 525-549$.

NAKANISHI, M. (1982) : Seasonal changes in the primary productivity of nanno-and netplankton in South basin of Lake Biwa. Survey Rep. Natl. Inst. Environ. Stud., No. 22 : 197-208.

NaKanishi, M., T. Narita, O. Mitamura, N. Suzu$\mathrm{KI}$, and K. OKAMOTO (1986) : Horizontal distribution and seasonal changes of chlorophyll $a$ concentration in the south basin of Lake Biwa. Jpn. J. Limnol., $47: 155-164$.

OECD (1982): Eutrophication of Waters. pp.1-154. OECD, Paris.

Otsuki, A. T. Iwakuma, T. Kawai and M. AizaKI (1984): The trends in eutrophication of Lake Kasumigaura. Res. Rep. Natl. Inst. Environ. Stud., No. $51: 1-10$ (in Japanese).

Pollingher, U. and T. BERMAN (1977) : Quantitative and qualitative changes in the phytoplankton of Lake Kinneret, Israel (1972-1975). Oikos, 29 : $418-428$.

Ruggiu, D. and C. SARAceni (1977) : Fitiplancton e produzione primaria nel Lago Maggiore durante gli anni 1972-1973. Mem. Ist. Ital. Idrobiol., 34 : 57-78.

Ruggiu, D., C. Saraceni, T. D. Bortoli, and M. NAKANISHI (1979) : Primary production in Lago
Di Mergozzo (N. ITALY) and implication of phytoplankton cell size. Mem. Ist. Ital. Idrobiol., $37: 223-246$.

RoBERTS, R. D. (1979) : Underwater light penetration, chlorophyll $a$ and primary production in a tropical African lake (Lake Mcllwaine, Rhodesia). Arch. Hydrobiol., 86 : 423-444.

RoBERTS, R. D. (1984) : Factors controlling primary production in a hypertrophic lake (Hartbeespoort Dam, South Africa). J. Plankton Res., 6 : $91-105$.

SAKamoto, M., H. Kurasawa and T. OKInO (1975) : Productivity and nutrient metabolism of communities in Lake Suwa. p. 107-147. In S. MoRI and G. YамAмото (eds.) JIBP Synthesis, 10.

SARACENI, C., D. RuggiU, and M. NAKANISHI (1978) : Phytoplankton dynamics, chlorophyll $a$ and phaeophytin in Lago Di Mergozzo (North Italy). Mem. Ist. Ital. Idrobiol., $36: 215-237$.

SMiTH, E. L. (1936) : Photosynthesis in relation to light and carbon dioxide. Proc. Natl. Acad. Sci. USA., 22 : 504-511.

STRATHMANN, R. R. (1967) : Estimating the organic carbon content of phytoplankton from cell volume or plasma volume. Limnol. Oceanogr., $12: 411-418$.

SugiURA, N. and A. IIZIMA (1978) : Seasonal changes in the phytoplankton biomass in Lake Kasumigaura. J. Water Waste, $20: 1233-1241$.

Sugiura, N., H. TAKAyANAgI, and R. Sudo (1982) : Changes of phytoplankton in Lake Kasumigaura. J. Water Waste, $24: 1253-1260$.

Sunou, M., I. Nakano, N. Hashitani and T. KaseBAYASHI (1960) : Limnological Studies of Lake Kasumigaura and Kitaura. Fishery office of Ibaraki Prefecture. $5: 37-46$ (in Japanese).

Takamura, K., Y. Sugaya, N. Takamura, T. HANAZATO, M. YASUNO, and T. IwAKUMA (1988) : Primary production of phytoplankton and biomasses of zooplankton and zoobenthos in hypertrophic Lake Tegamuna. Hydrobiologia (in press).

TAKAMURA N., T. IwAKUMA and M. YAsUno (1984): The biomass and production of phytoplankton in Lake Kasumigaura during 1981-1983. Res. Rep. Natl. Inst. Environ. Stud., No. $51: 11-56$ (in Japanese).

TAKAmura, N., T. IwaKuma and M. Yasuno (1985): Photosynthesis and primary production of Microcystis aeruginosa $\mathrm{K} \ddot{\mathrm{u}} \mathrm{tz}$. in Lake Kasu- 
migaura. J. Plankton Res., 7 : 303-312.

TaKamura, N., T. Iwakuma, and M. Yasuno (1986) : photosynthesis of size-fractionated phytoplankton population in hypertrophic Lake Kasumigaura, Japan. Arch. Hydrobiol., 108 : 235-257.

TAKAMURA, N., T. IWAKUma, and M. Yasuno (1987) : Uptake of ${ }^{13} \mathrm{C}$ and ${ }^{15} \mathrm{~N}$ (ammonium, nitrate and urea) by Microcystis in Lake Kasumigaura. J. Plankton Res., $9: 151-165$.

TAnge, M., T. Kasebayashi, G. Koide and T. HaYASHI (1957) : Limnological Studies of Lake Kasumigaura (1950). Fishery center of Ibaraki Prefecture. 2:1-10 (in Japanese).

Tezuka, Y., Y. Watanabe, H. Hayashi, M. Aizaki, and T. Maruyama (1973) : Water quality, biomass of bacteria, and the primary production. Biological survey report of Lake Kasumigaura. p. 171-191. (in Japanese).

Tezuka, Y., H. Hayashi, M. Aizaki, T. Nakazima, M. OchiaI, N. NAKAMOTO and T. Kono (1975) : Bacterial biomass and primary production. Biological survey report of Lake Kasumigaura. p. 79-117. (in Japanese).

UNESCO/SCOR (1966) : Determination of photosynthetic pigments in seawater. Monogr. Oceanogr. Methodol., 1-69.

UTERMÖHL, H. (1958) : Zur Vervollkommung der quantitativen phytoplankton-Methodik, Mitt. Int. Ver. Theor. Angew. Limnol., 9: 1-38.

VARESCHI, E. (1982) : The ecology of Lake Nakuru (Kenya) III. Abiotic factors and primary production. Oecologia (Berl.), $55: 81-101$.

Vollenweider, R. A. (1965) : Calculation models of photosynthesis-depth curves and some implications regarding day rate estimates in primary production measurements. Mem. Ist. Ital. Idrobiol. Suppl., $18: 425-457$.

VOLLENWEIDER, R. A. (1974) : Environmental factors linked with primary production, p. 157-177. In R. A. Vollenweider (ed.), A Manual on Methods for Measuring Primary Production in Aquatic Environments. Blackwell Scientific Publications, Oxford.

WiLLÉN, E. (1976a) : Phytoplankton and environmental factors in Lake Hjä Imaren, 1966-1973. Staten naturevardsverk PM 718. Naturevardsverkets Limnol. Unders., 87.

WiLLÉN, E. (1976b) : Phytoplankton in Lake Hjä rmaren. Acta Univ. Upsal., $378: 1-18$.

WILLÉN, E. (1984): The large lakes of sweden : $\mathrm{V}$ ä nern, $\mathrm{Vättern,} \mathrm{Mälaren}$ and $\mathrm{Hjälmaren.} \mathrm{p}$. 107-134. In F. B. TAUB (ed.), Lakes and Reservoirs. Elsevier science publishers B. V., Amsterdam.

Wood, R. B. and C. E. GIBSON (1973) : Eutrophication and Lough Neagh. Water Res., $7:$ 173187.

Yaguchi, M., M. Sunou, I. Nakano and N. HasitaNI (1961a) : Limnological Studies of Lakes Kasumigaura and Kitaura. Fishery office of Ibaraki Prefecture. 6: 81-93 (in Japanese).

YAGUCHI, M., M. SUnOU, and I. NAKANo (1961b) : Limnological Studies of Lakes Kasumigaura and Kitaura (1969). Fishery office of Ibaraki Prefecture. $6: 95-105$ (in Japanese).

YAMAGUCHI, Y. and S. ICHIMURA (1975) : Phytoplankton and primary production. p.72-74. JIBP Synthesis, 10.

（著者：高村典子・岩熊敏夫・安野正之, 国立公害研 究所生物環境部, 戸305 茨城県つくば市小野川 162 ; Noriko TAKamURa, Toshio IwaKUma and Masayuki YAsuNo, National Institute for Environmental Studies, Tsukuba 305 Japan)

Received : 6 June 1987 Accepted : 6 November 1987

\section{Appendix}



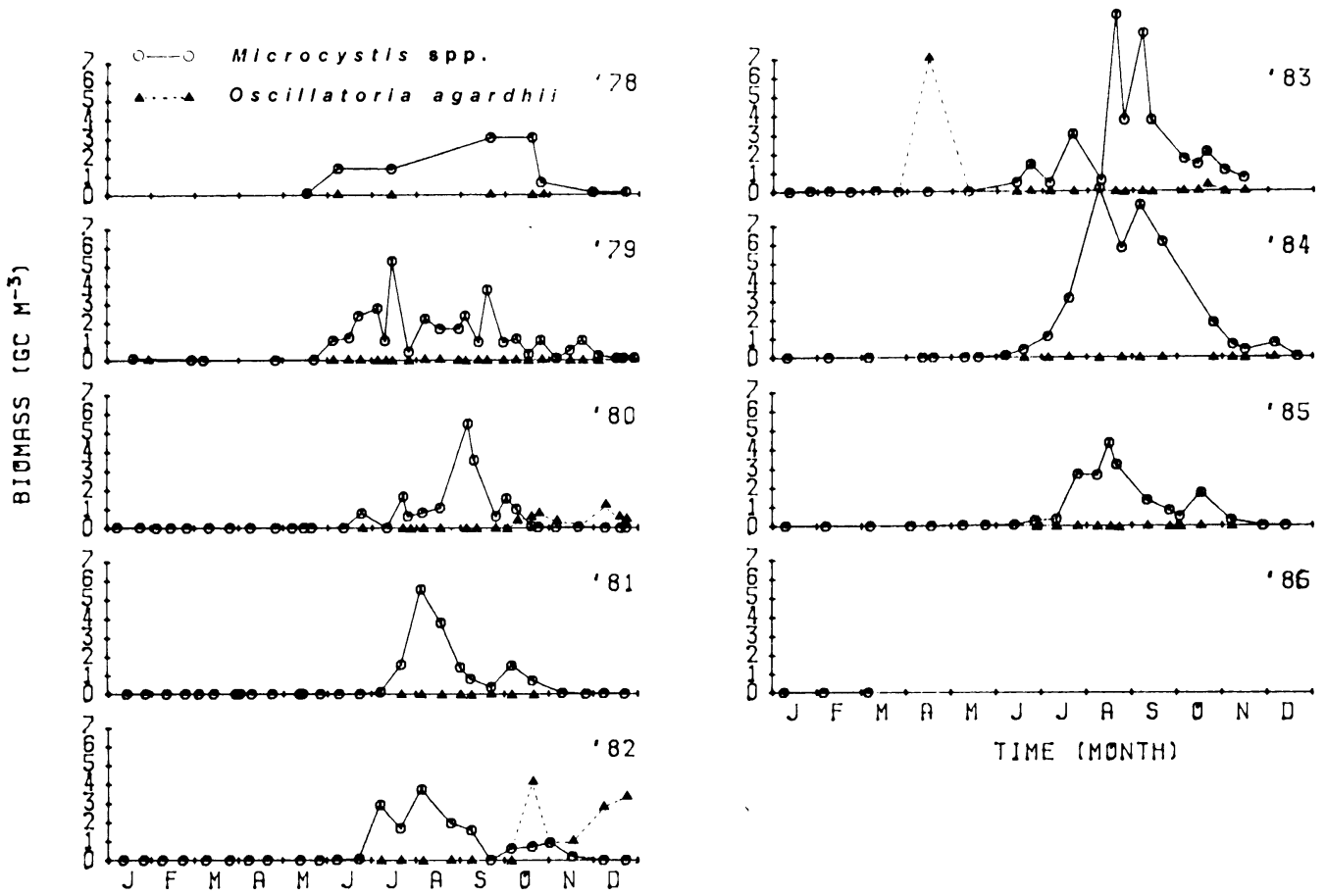

TIME (MONTH)

TIME (MONTH)
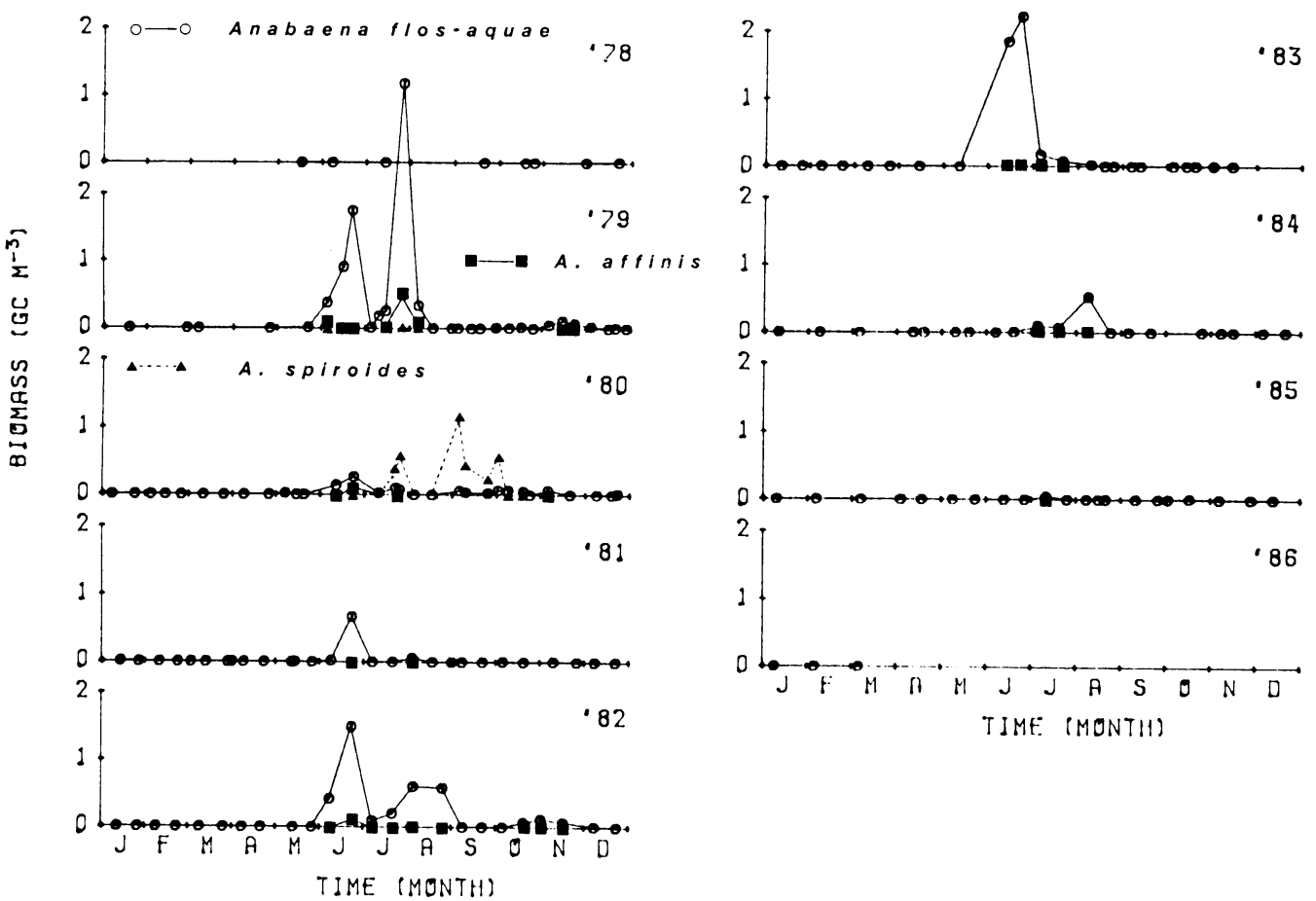

TIME: (MONTH)

Fig. A-1. Seasonal changes in the biomass of main species of phytoplankton at the center of Takahamairi Bay (Sta. 3). 

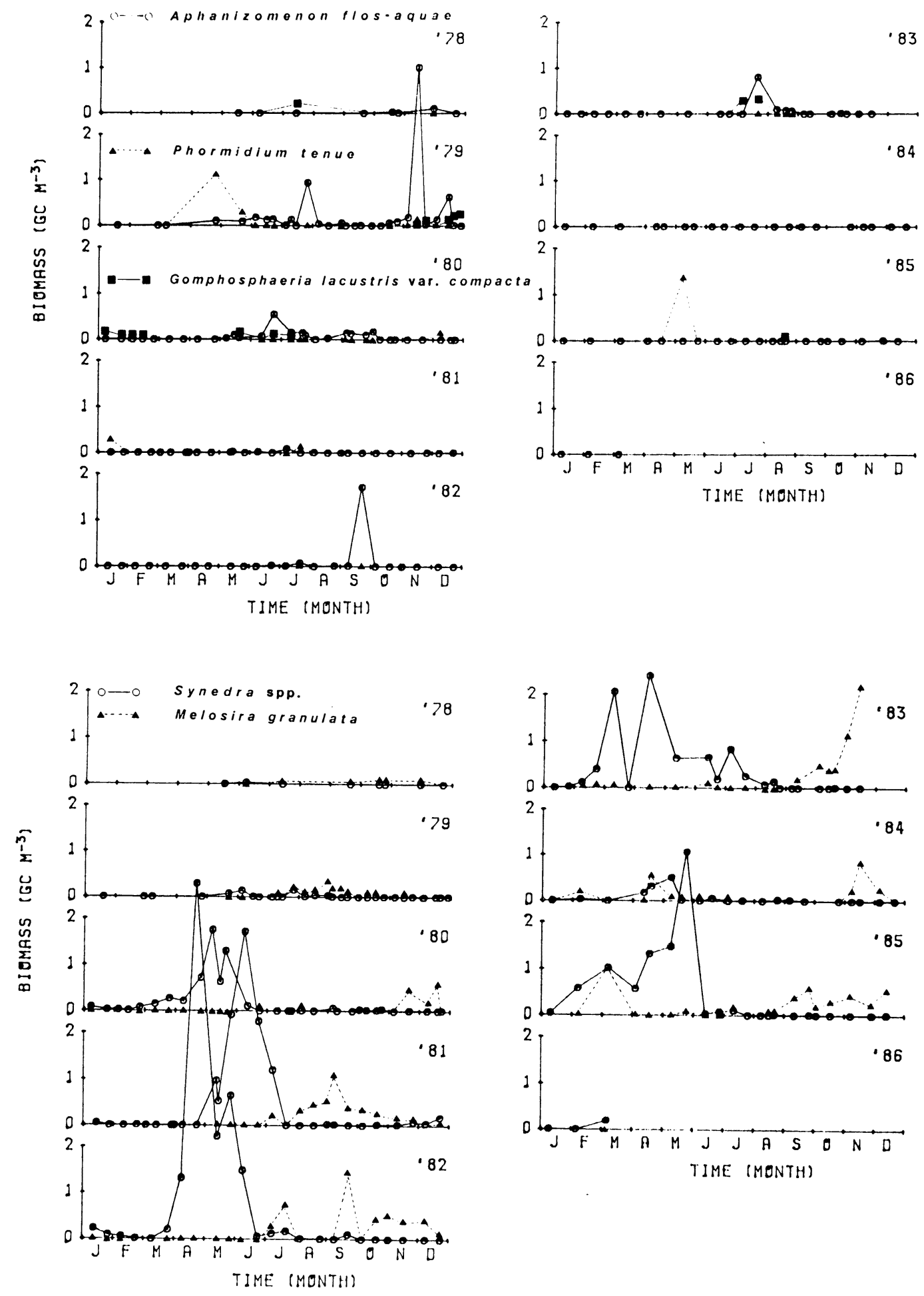

Fig. A-1. Continued. 

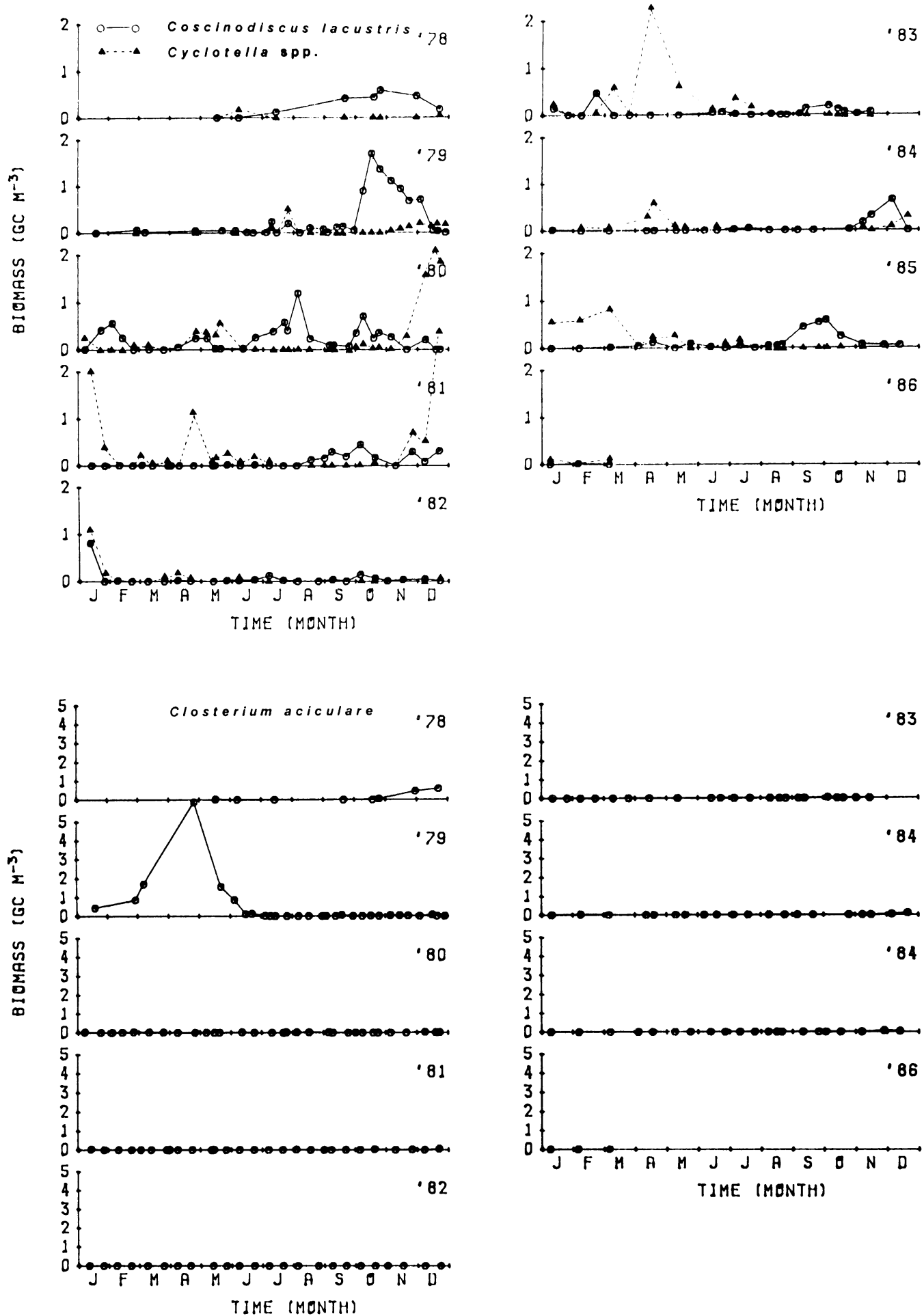

Fig. A-1. Continued. 

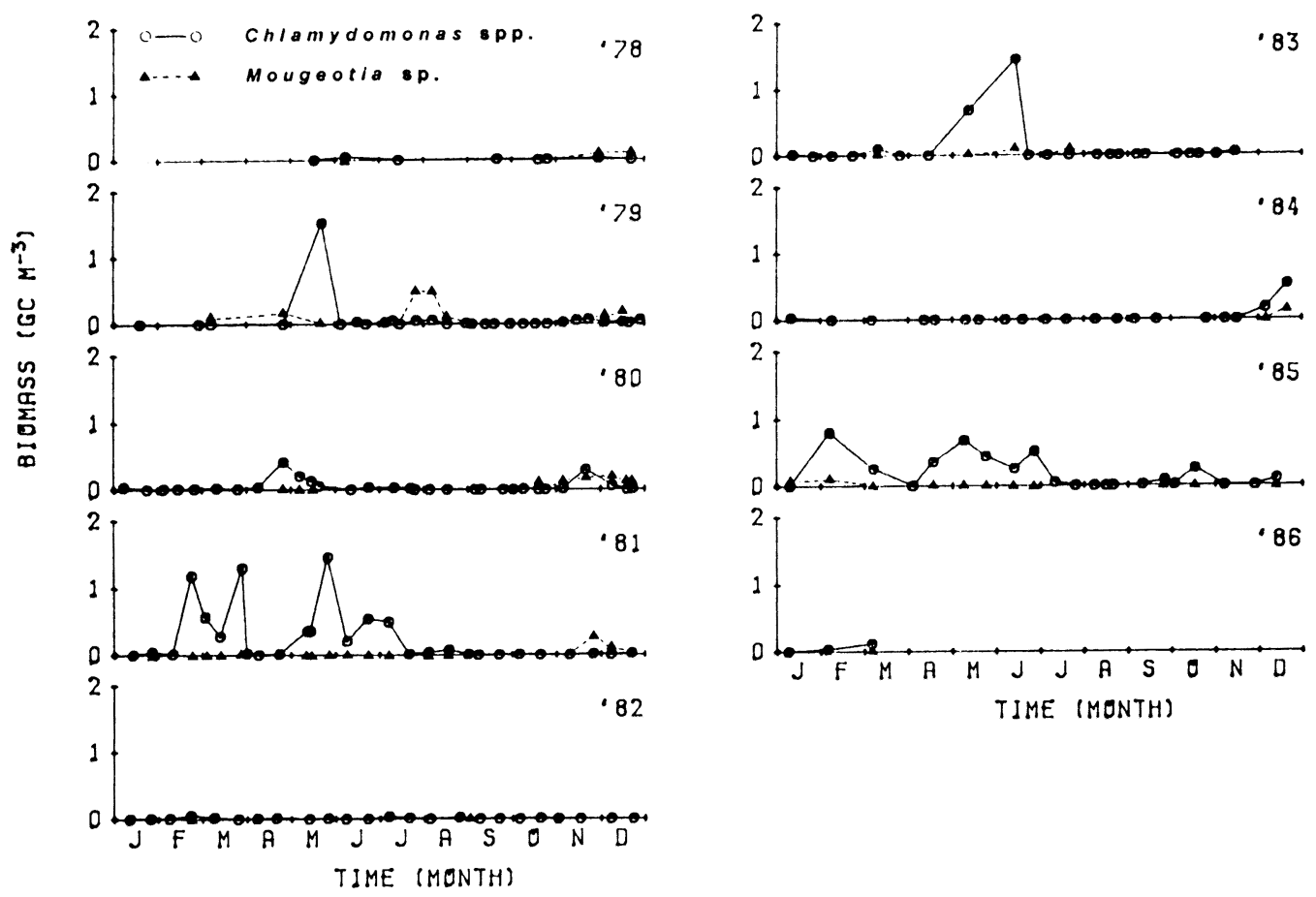

TIME (MONTH)
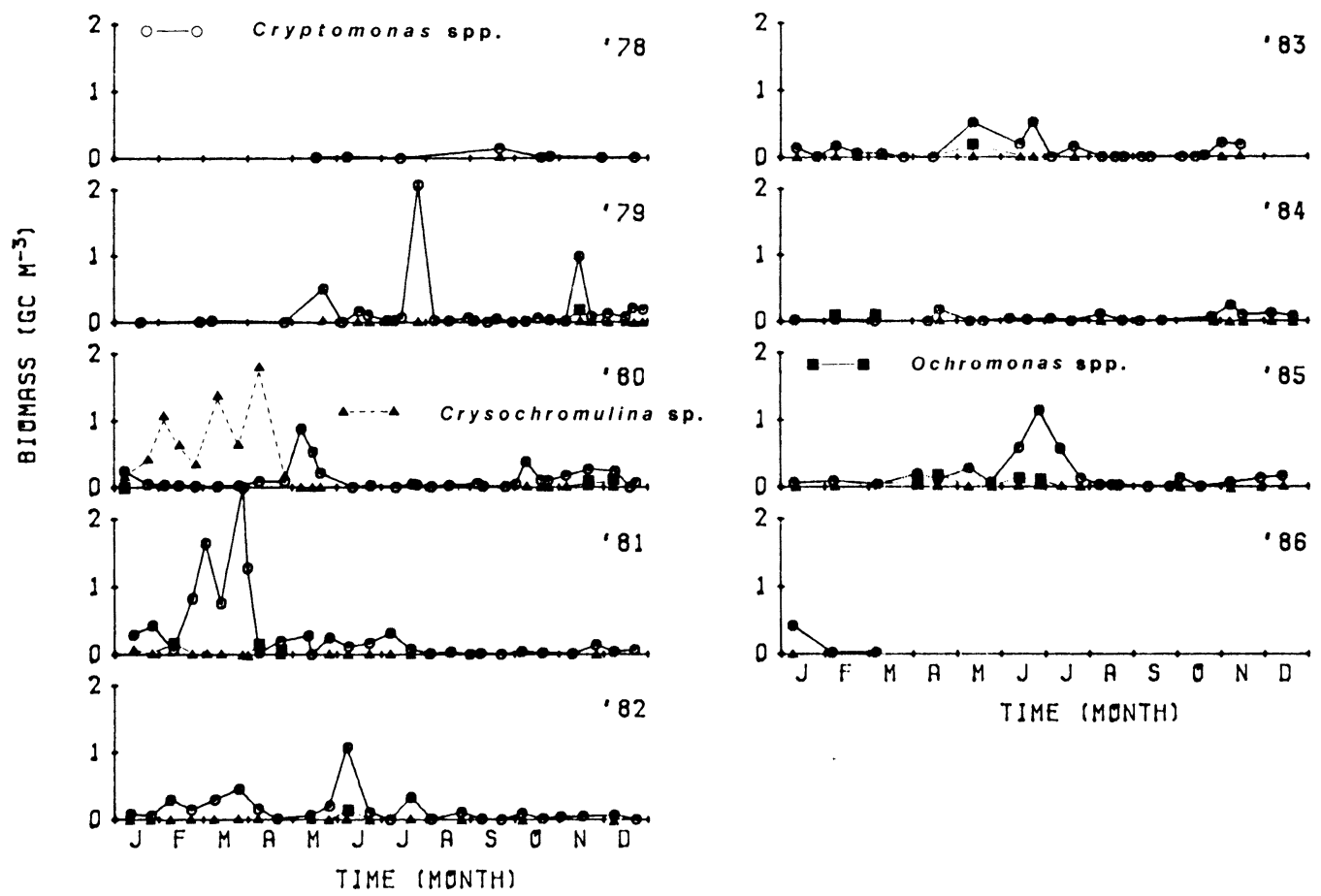

Fig. A-1. Continued. 

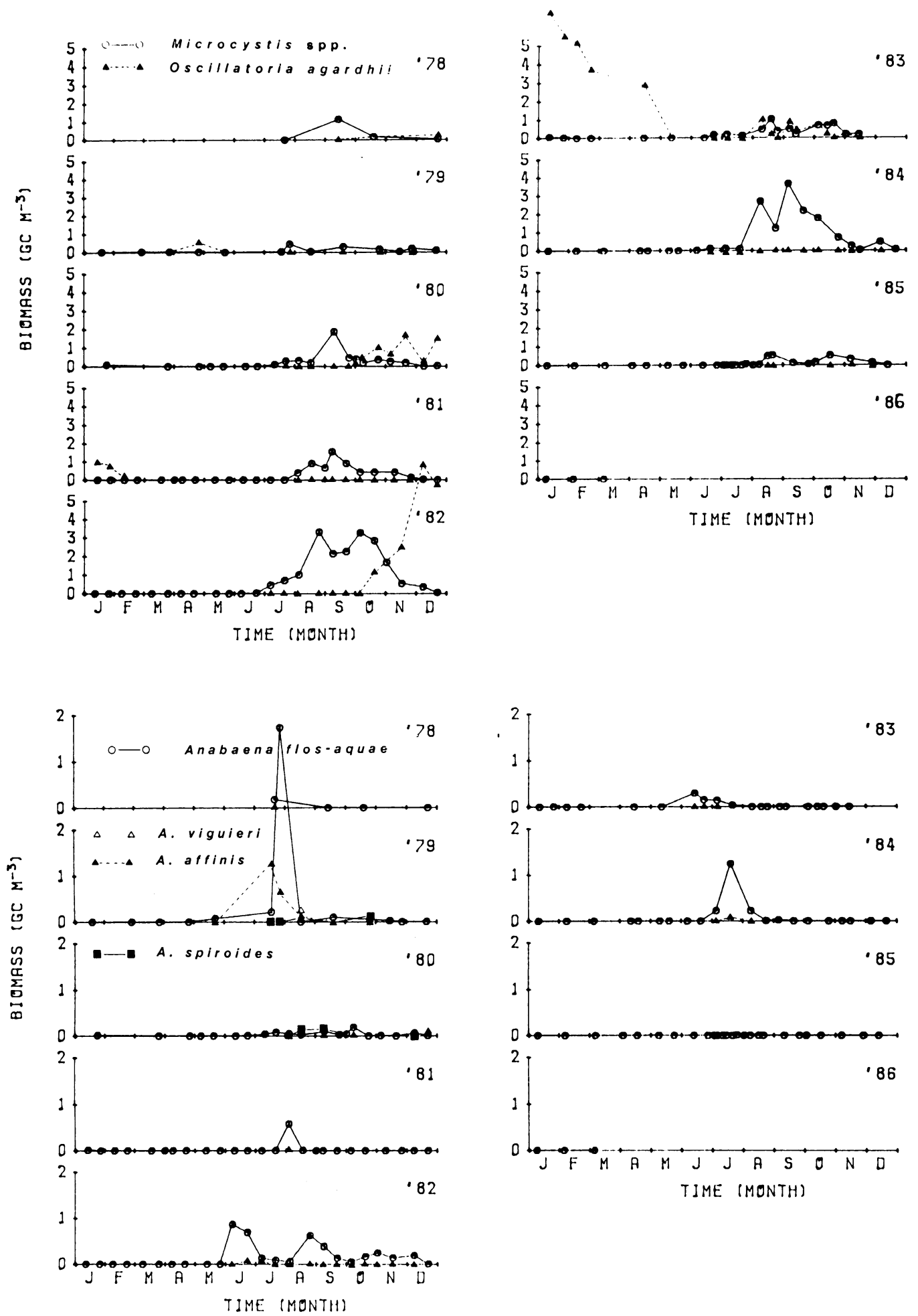

TIME (MONTH)

Fig. A-2. Seasonal changes in the biomass of main species of phytoplankton at the center of main basin (Sta. 9). 

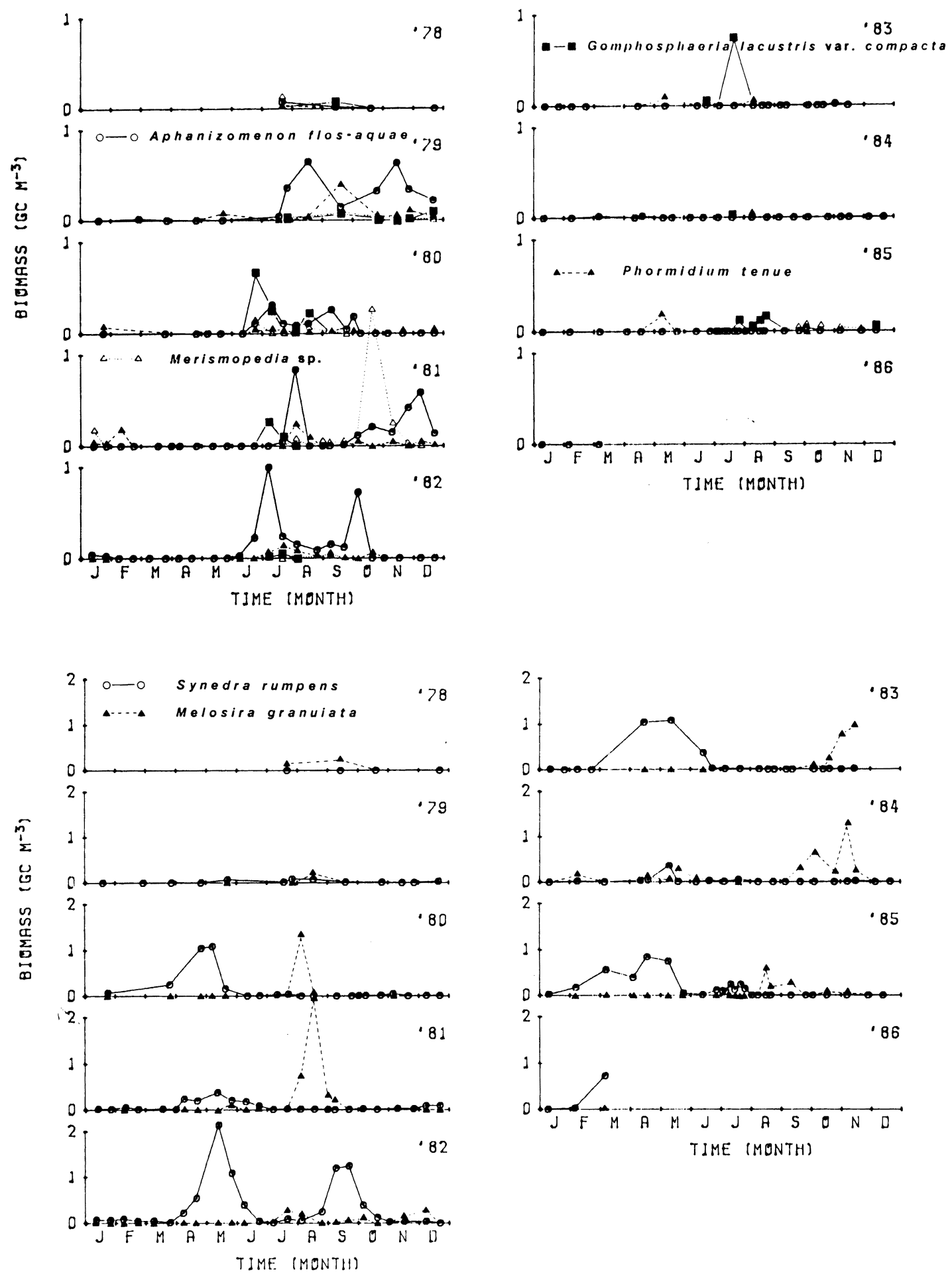

Fig. A-2. Continued. 

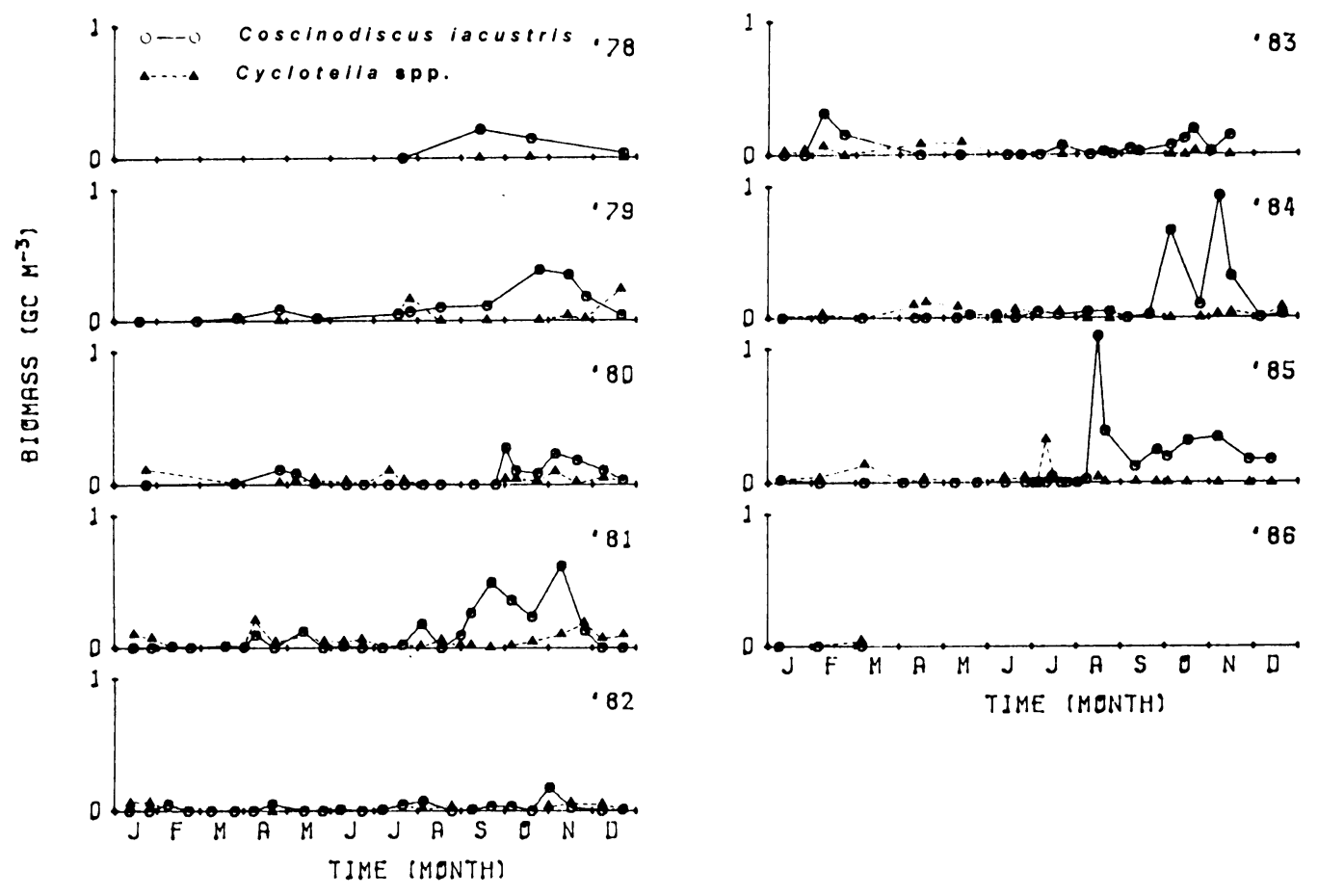

TIME (MONTH)
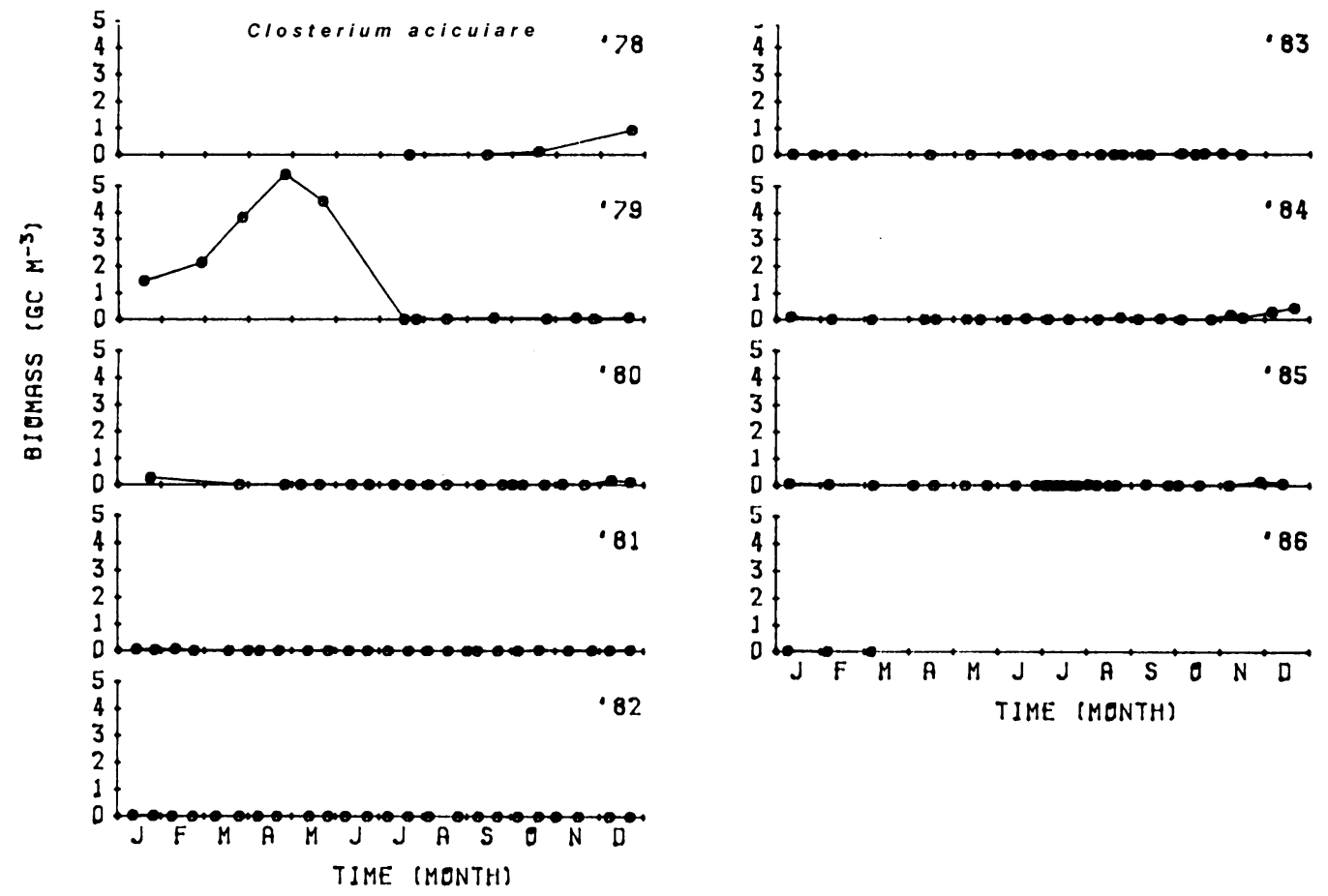

TIME (MONTH)

Fig. A-2. Continued. 

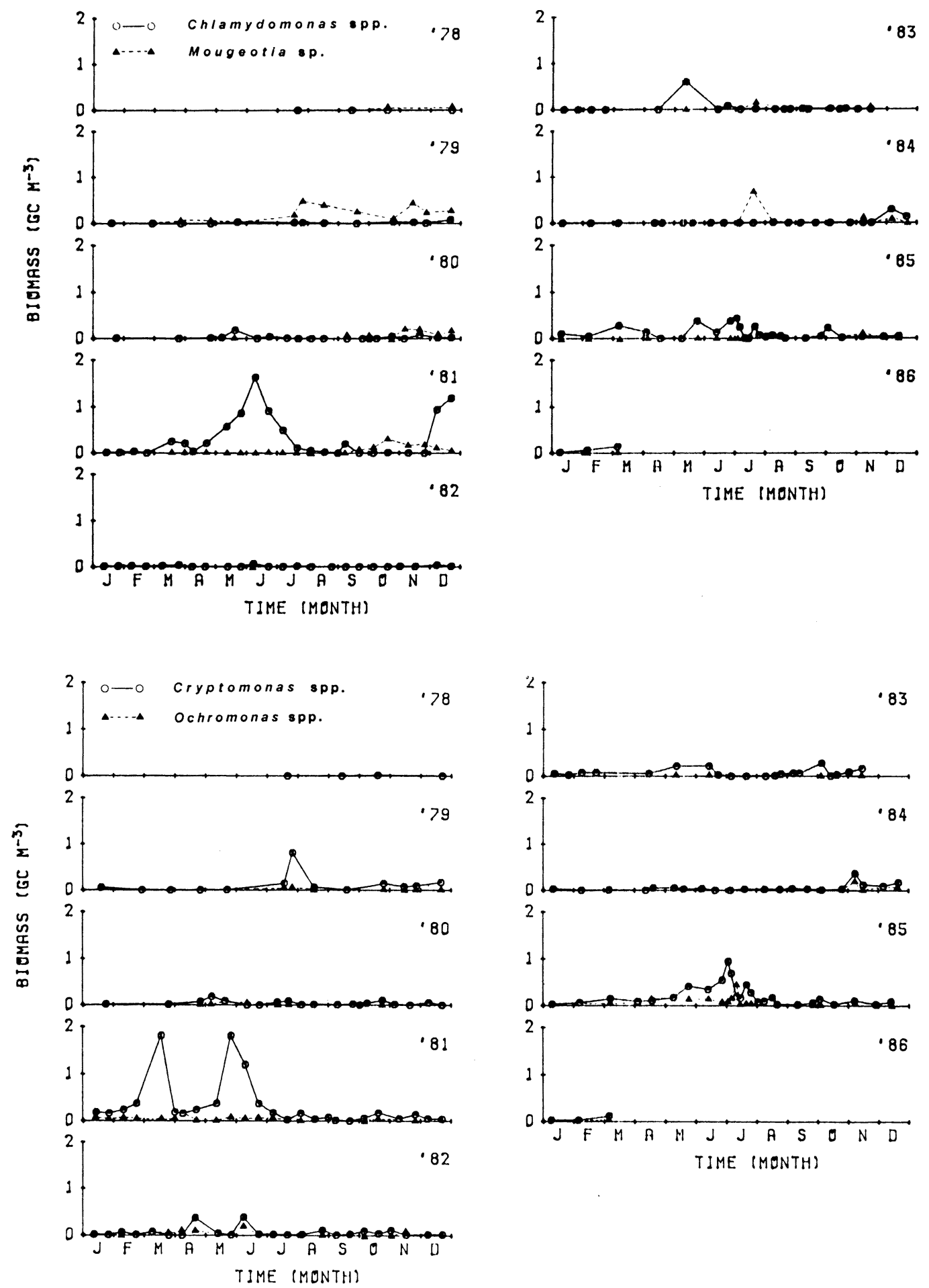

Fig. A-2. Continued. 